The Effects of a Sick Pay Reform on Absence and on Health-Related Outcomes

Patrick A. Puhani and Katja Sonderhof

December 2009 Discussion Paper no. 2009-34 


$\begin{array}{ll}\text { Editor: } & \text { Martina Flockerzi } \\ & \text { University of St. Gallen } \\ & \text { Department of Economics } \\ & \text { Varnbüelstrasse 19 } \\ & \text { CH-9000 St. Gallen } \\ & \text { Phone } \quad+41712242325 \\ & \text { Fax } \quad+41712243135 \\ & \text { Email vwaabtass@unisg.ch } \\ & \text { Department of Economics } \\ & \text { University of St. Gallen } \\ & \text { Varnbüelstrasse 19 } \\ \text { Publisher: } & \text { CH-9000 St. Gallen } \\ & \text { Phone +41 71 224 23 25 } \\ & \text { Fax } \quad+41712243135 \\ & \text { http://www.vwa.unisg.ch }\end{array}$




\title{
The Effects of a Sick Pay Reform on Absence and on Health-Related Outcomes $^{1}$
}

Patrick A. Puhani and Katja Sonderhof

Author's address:

\author{
Patrick Puhani \\ Leibniz Universität Hannover \\ Institut für Arbeitsökonomik \\ Königsworther Platz 1 \\ D-30167 Hannover \\ Phone + 495117625620 \\ Email_puhani@aoek.uni-hannover.de \\ Katja Sonderhof \\ Leibniz Universität Hannover \\ Institut für Arbeitsökonomik \\ Königsworther Platz 1 \\ D-30167 Hannover \\ Phone + 495117625657 \\ Email_sonderhof@aoek.uni-hannover.de
}

\footnotetext{
${ }^{1}$ This research was supported by the German Research Foundation (DFG) within the project 'Labour Market Effects of Social Policy' which is part of the research initiative 'Flexibility in Heterogeneous Labour Markets'. We are grateful to Christian Dustmann, John Heywood, Jeff Smith, Fan Wu, two anonymous referees and seminar participants at Cornell University; EEA (Barcelona); ERMES, University of Paris II; Hebrew University; Tel Aviv University; University of Hannover; University of Magdeburg; University of Michigan; University of Wisconsin-Milwaukee; and ZEW, Mannheim, for helpful comments. All remaining errors are our own.
} 


\begin{abstract}
We evaluate the effects of a reduction in sick pay from 100 to $80 \%$ of the wage. Unlike previous literature, apart from absence from work, we also consider effects on doctor/hospital visits and subjective health indicators. We also add to the literature by estimating both switch-on and switch-off effects, because the reform was repealed two years later. We find a two-day reduction in the number of days of absence. Quantile regression reveals higher point estimates (both in absolute and relative terms) at higher quantiles, meaning that the reform predominantly reduced long durations of absence. In terms of health, the reform reduced the average number of days spent in hospital by almost half a day, but we cannot find robust evidence for negative effects on health outcomes or perceived liquidity constraints.
\end{abstract}

\title{
Keywords
}

Sickness pay, absenteeism, health expenditure, hospitalization, difference-indifferences, switch on, switch off, quantile regression, intrinsic motivation.

\section{JEL Classification}

I18, J58, J83 


\section{$1 \quad$ Introduction}

Sick pay and disability insurance programs, while reducing exposure to risk and seeking to promote equity through support of people in need, entail moral hazard problems. Several studies on U.S. and Canadian disability schemes find negative labor supply and positive take-up effects of increased benefit generosity as well as effects of economic conditions on benefit take up (Black, Daniel and Sanders, 2002; Gruber, 2000; Johnson and Ondrich, 1990; Kreider and Riphahn, 2000; Meyer, Viscusi and Durbin, 1995; Neuhauser and Raphael, 2004; on screening, see Campolieti, 2004). Gruber (2000) stresses that the U.S. disability program is "one of the largest social insurance programs" with an expenditure that amounts to \$46 billion, which was 0.13\% of U.S. GDP in 1998.

Unlike the U.S. or the U.K., several continental European countries require employers to provide sick pay from day one of each sickness spell. In Germany, Europe's largest economy, sick pay is $100 \%$ of the wage for the first six weeks of sickness. Combined with the high level of employment protection typical of many continental European economies, these regulations make absence hard to sanction. ${ }^{1}$ As a consequence, presence at the workplace is - at least in the short run when promotion is disregarded - a form of voluntary cooperation by the worker. Absence from work carries a high cost in terms of workdays lost, with rates ranging from $2.0 \%$ in the U.S. to 4.2 or $7.2 \%$ in continental European countries like Germany or France, respectively (Osterkamp, 2002). If the cost of sick pay regulations in Germany were compared to the U.S. disability program, a back-of-the envelope calculation would dwarf the size of the U.S. disability program in terms of percentage of GDP spent in the respective country: if labor contributed two-thirds to the GDP, a reduction in working days lost from the German to the U.S. level would raise the GDP by about $2.2 \times(2 / 3)=$

\footnotetext{
${ }^{1}$ In Germany and Sweden, a worker can remain absent from work for 2 and 7 days, respectively, without a physician's certificate (Johansson and Palme, 2005; Riphahn and Thalmaier, 2001).
} 
$1.5 \%$, more than eleven times the cost of the U.S. disability program in percentage of U.S. GDP. ${ }^{2}$

In this study, we extend the recent literature using natural experiments to estimate the effects of incentives on absence (Henrekson and Persson, 2004; Ichino and Riphahn, 2005; Johansson and Palme, 2002, 2005; Riphahn, 2004; Riphahn and Thalmaier, 2001). However, unlike previous studies, we do not only consider absence from work as an outcome, but also estimate the reform's effects on health-related outcomes like the duration of hospital stays and subjective health indicators and show that moral hazard problems of sick pay extend to inefficient use of the medical system. We further add to the literature by estimating the effects of the introduction (switch on) and then repeal of a reform (switch off) that reduced sick pay in Germany from 100 to $80 \%$ of the wage. Methodologically, because this reform affected only workers not covered by collective bargaining contracts, we can apply a difference-in-differences identification strategy to German Socio-Economic Panel data so as to distinguish the effects of the reform from time- or group-specific effects. Fixed-effects regressions provide an additional control for unobserved individual heterogeneity.

The relationship between financial incentives and absence is amply shown in earlier papers using regression analysis on observational data (i.e., without natural experiments). Fewer studies, however, use natural experiments to relate the cost of absence to its incidence or duration. Ichino and Riphahn (2005), Riphahn and Thalmaier (2001), and Riphahn (2004) exploit probationary periods or time to reach virtually "undismissable" status as a natural experiment which leads to high employment protection. The authors find that absence rates increase with employment protection in Italy and Germany. For Sweden, Henrekson and Persson (2004) use time series data for 1955-1999 to show that reforms that make sick pay more generous increase absence from work and vice versa. Likewise, Johansson and Palme

\footnotetext{
${ }^{2}$ Admittedly, this number may be somewhat lower if genuinely sick employees going to work are not only less productive but may also decrease the productivity of others through infection, yet $1.5 \%$ of the GDP is a large enough number to illustrate the potential importance of policies affecting workers' absence.
} 
(2002, 2005) use person-level data to evaluate the Swedish sick pay reform of 1991, which resembled that investigated here for Germany but applied only to blue-collar workers. The authors identify reactions to the incentives created by the reform: both the incidence and the duration of absence decreased when the cost of absence increased.

This present paper investigates the case of the late 1996 German reform that reduced sick pay from 100 to $80 \%$ during the first 6 weeks of sickness for workers without collective bargaining contracts. However, unlike previous studies using natural experiments to evaluate the incentives linked to sick pay, we can also evaluate the effects of the early 1999 repeal of the reform, which re-set sick pay to $100 \%$ of the wage rate from day 1 . Apart from absence from work (the outcome considered in the previous literature), we also evaluate the reform's effects on use of the medical system and on subjective health indicators. Specifically, we find that for workers aged 20 to 55 years who remained with their firm during the estimation period, the average number of days absent from work fell by 2.4 days per year (according to a fixed-effects estimate). Furthermore, we show that the reform particularly reduced long durations of absence and that part of this decrease ( 0.4 days) coincides with a reduction in the average number of days spent in hospital, although we cannot find any robust effects of the reform on subjective health indicators. The results also indicate that the switch-on effects of the reform might be slightly smaller than the switch-off effects on absence from work. However, this difference is not statistically significant. Altogether, it seems that the reform reduced the - in international comparison - long and frequent contacts of Germans with their health care system. These contacts are costly both for employers and the health care system, but their reduction due to the sick pay reform seemingly had no statistically robust negative effects on subjective health indicators or in terms of long-term sickness. We also find no negative effects of the reform on liquidity constraints, measured as the perception of financial security in case of sickness. 


\section{$2 \quad$ Sick Pay in Germany}

Germany has one of the most generous sick pay regulations among industrialized countries. German federal law dictates that employees reporting sick are entitled to $100 \%$ of their pay for the first 6 weeks of sickness, to be paid by the employer (Bundesministerium der Justiz, 2003; Schmitt, 2005). Only after this period does the percentage reduce to the $70 \%$ covered by mandatory health insurance (Bundesministerium der Justiz, 2008). ${ }^{3}$ Moreover, in contrast to regulations in the U.S., the U.K. or Switzerland, German federal law regulates sick pay for the first few days of illness (Osterkamp, 2002).

As of October 1, 1996, the Christian Democrat and Liberal coalition government reformed the federal law regulating sick pay in Germany so that all employees (whether blueor white-collar) were entitled to only $80 \%$ (rather than $100 \%$ ) of their previous wage from day 1 of sickness through the first 6 weeks of absence (Schmitt, 2005). ${ }^{4}$ This law, however, was heavily resisted by the trade unions, which prior to 1970 had fought for years to gain $100 \%$ sick pay for all workers. Hence, the implementation of the new law was followed in 1996 and 1997 by a plenitude of lawsuits (each referring to a particular collective bargaining contract) in which the unions argued that collective bargaining contracts based on the old version of the law were still valid and implied sick pay corresponding to $100 \%$ of the wage. According to Bispinck and WSI-Tarifarchiv (1997), these lawsuits were generally won.

\footnotetext{
${ }^{3}$ Some employees are subject to more generous sick pay rules arrived at through collective bargaining agreements. For example, public sector employees already in place before July 1, 1994, receive sick pay of $100 \%$ of their wage for more than 6 weeks depending on their tenure $(9,1215,18$ and 26 weeks for $2,3,5,8$ and 10 years of tenure, respectively). For public sector employees hired after this date, the 6-week rule applies (Clemens et al., 2006). However, after the first 6 weeks, public sector employers must pay an additional allowance into the $70 \%$ sick pay covered by the mandatory health insurance. Such allowances in addition to health insurance sick pay after the sixth week of sickness also exist in other sectors of the economy and depend on the specific collective bargaining contract.

${ }^{4}$ Besides reducing the sick pay covered by the employer for the first 6 weeks, the January 1, 1997, changes to the law on mandatory health insurance reduced sick pay from the 7th week onwards (covered by mandatory health insurance) from 80 to $70 \%$ (Bundesministerium der Justiz, 1996). This type of sick pay is paid for up to 78 weeks within 3 years for a single type of sickness (Bundesministerium der Justiz, 2008). It should also be noted that this reform (the reduction from 80 to $70 \%$ ) had not been reversed by the time of writing. There was also a small reform of hospital stay co-payments. In 1994, co-payments were DEM 14 (€7) per day in Western Germany and DEM $9(€ 4.50)$ in Eastern Germany. In 1997, they were slightly raised to DEM 17 $(€ 8.50)$ and DEM $14(€ 7)$ in Western and Eastern Germany, respectively. Although the reform of 1997
} 
Hence, as of December 1997, over 15 million employees were covered by collective

bargaining contracts that guaranteed them sick pay of $100 \%$ of their wage, which implies full coverage of about $55 \%$ of all employees (not counting civil servants, who were not affected by the reform). Indeed, according to a 1998 publication by the German Parliament

(Deutscher Bundestag), $80 \%$ of employees were receiving sick pay corresponding to $100 \%$ of their wage, and the remaining $20 \%$ were largely those not covered by collective bargaining contracts (Deutscher Bundestag, p. 17). ${ }^{5}$

This group of workers without collective bargaining coverage comprise our treatment group, which we compare to the control group of workers covered by collective bargaining contracts using a difference-in-differences estimation strategy. Nevertheless, some measurement error can be expected in the treatment status for two major reasons. First, some workers in our control group did in fact receive "treatment" because their collective contract did not provide for sick pay covering $100 \%$ of their wage. Second, more workers received treatment immediately after the reform became effective (October 1, 1996) than by the middle of 1997 or later because it took time for lawsuits to establish that the old rules applied for most workers covered by collected bargaining. Both these sources of measurement (classification) error are likely to lead to an attenuation bias; that is, because estimates of the treatment effect are biased toward zero, the true effects might be larger than those estimates. ${ }^{6}$ However, we assessed the second measurement problem by producing estimates using only

concurs with the treatment period, the raise of co-payments by $€ 1.50$ in Western Germany (€2.50 in Eastern Germany) is minute compared to the cut in wages by 20 percent for each sickness day.

${ }^{5}$ We could not find other statistics on the share of employees who still obtained $100 \%$ of their wage as sick pay. We did contact all major trade unions, but most information they provided referred to regulations in specific contracts rather than statistics on the number of employees covered by different sick pay regimes.

${ }^{6}$ As surveyed in Bound, Bown and Mathiowetz (2001, p. 3725), classification error (measurement error in a binary variable) usually leads to bias towards zero, unless classification error is so prevalent that the sign of the estimate actually changes. The statement by the German parliament (Deutscher Bundestag) above in the text, however, suggests that the overlap between collective bargaining coverage and not being affected by the reform turned out to be almost perfect so that we have to assume that classification error leads to small attenuation bias in our application. In the difference-in-differences context, the classification bias affects the coefficient of the dummy variable of the treatment group indicator. However, the interaction coefficient of interest, namely the coefficient on the interaction between the treatment indicator and the reform period will also be attenuated because only part of the indicated treatment group will actually have been treated. This implies that the true effects are probably even somewhat larger than the ones we estimate. 
1998 as the treatment period thus ignoring 1997 (a time of ongoing lawsuits). These

estimates were similar to our main results, so we could not find evidence for attenuation bias.

Two years after the late 1996 reduction in sick pay, the right-wing coalition government between the Christian Democrats and the Liberals ended after a regular election installed a left-wing coalition government between the Social Democrats and the Green Party. As a result, on January 1, 1999, only two months after the change of government, the 1996 sick pay reform was repealed. This introduction and then repeal of the reform within such a short period allows us to estimate the effects of reduced sick pay through both the switch-on and switch-off effects of the policy change.

Methodologically, the question arises whether policy endogeneity or anticipation effects may bias our estimates. However, any transitory developments in absence from work or other health related outcomes that might have triggered policy reforms are taken care of by our difference-in-differences estimation strategy (as long as these shocks affected treatment and control groups similarly). Furthermore, an electronic search of a major German newspaper, the Frankfurter Allgemeine Zeitung, for articles on sick pay revealed that a motivation for the reduction in sick pay were not a recent rise in absence rates, but a gradual realization that the German labor market regulations built up over decades had reduced labor market competitiveness. Furthermore, the debate on the reform only heated up after April $6^{\text {th }}$ 1996, when the Minister of Labor proposed changes to sick pay, that is already after our prereform years 1994 and 1995. The law was passed on September 13, 1996, only slightly more than 2 weeks before it became effective.

\section{Data and Descriptive Statistics}

To the best of our knowledge, the German Socio-Economic Panel (GSOEP), in existence since 1984, is the only person-level dataset providing information on both workers' absence from work and worker coverage by collective bargaining contracts. Whereas 
information on absence, asked as the number of days the worker was absent from work in the previous year, is collected annually, information on a worker's coverage by a collective bargaining contract is only available for the 1995 survey. However, because average tenure in Germany is longer than in the U.K. or the U.S. (in 1998, 10.4 years versus 8.2 and 6.6 years, respectively; Auer and Cazes, 2000), one option for the empirical strategy is to use the 1995 information on coverage by a collective bargaining contract and impute this value for each individual in all other waves. Nevertheless, because an employee may alter the treatment status by changing employer, this procedure may blur the partition of the sample into treatment and control groups to produce a third source of potential attenuation bias in our estimates (see Section 2). We therefore restrict the sample to workers who did not change employer during the years under consideration (hereafter, "firm stayers"). ${ }^{7}$ Specifically, this means that when defining treatment and control groups, we include only workers who responded to the 1995 question on collective bargaining coverage and did not change employer during the 1996/1997/1998 period when reduced sick pay was in place (the treatment period). Appendix Table A1 and Table A2 detail our selection of the estimation sample for this study. ${ }^{8}$

For the years prior to the reform, we use GSOEP data for 1994 and 1995 (days absent surveyed in 1995 and 1996, respectively) but exclude 1996 data because they could be partly affected by the October 1 implementation of the reform. In addition, 1996 was the beginning of the lawsuits clarifying that previous collective bargaining contracts made the reform

\footnotetext{
${ }^{7}$ It should be noted that in Germany, in contrast to some other countries, employers agreeing to a collective bargaining contract must apply its terms to all workers in the company, not simply to workers that belong to the trade union negotiating the contract. Employers can avoid collective bargaining contracts, however, by leaving the employers' federation. However, if employers had so changed their status, it would be yet another source of attenuation bias.

${ }^{8}$ In order to gauge whether these restrictions generate a selected sample, we regressed indicators for a) being a mover, b) for answering to the question on collective bargaining and on c) leaving the panel survey between 1995 and 1997 (panel attrition is an especially important issue for the fixed-effects estimators) on days of absence in 1995 (before the reform) and other controls. It turns out that a) being a mover and b) answering the question on collective bargaining coverage is not related to pre-reform absence, whereas c) leaving the panel is positively correlated with days of absence. Here, for the age group 20-55, which we mainly focus on,
} 
ineffective for most workers these contracts covered (see Section 2). These exclusions leave 1997 and 1998 as the viable years for examining effects when the reduced sick pay reform was in place (because of the 1997 lawsuits, we also check the sensitivity of our results when only 1998 is considered as the treatment year). Because the reform was repealed on January 1, 1999, GSOEP data referring to the years 1999 and 2000 provide the sample for the postreform period.

Table 1 displays the sample means by reform period (pre-reform, reform, post-repeal) and by coverage by collective bargaining. The sample consists of workers aged between 20 and 64 years who are not self-employed nor students or apprentices. Although the sample size changes across the years due to panel attrition and panel refreshment samples, it is lowest during the reform years because we exclude workers who changed employer during these years. Nevertheless, not only should the rich set of control variables contained in the GSOEP account for attrition based on observables, we also present fixed-effects estimates (see Section 4 below) that account for attrition based on unobserved variables as long as their effects are constant over time.

It should be noted, however, that as the outcome variable, we only observe the total number of absence/sickness days in a calendar year, not the number and length of specific sickness spells. Moreover, although the original GSOEP question asks about workdays lost due to illness, the fact that we observe some people reporting sickness durations exceeding the number of working days indicates that the measurement of absence might be a mix of lost workdays and the total number of sick days (including weekends and public holidays). ${ }^{9}$

increasing the days of absence by 50 days ( 50 days is already the $98^{\text {th }}$ percentile of days of absence) raises the probability of leaving the sample by 9.5 percentage points.

${ }^{9}$ The Ministry of Health also collects data on absence from the public health insurance system and publishes it on an annual basis. The average absence rates (percent of working days lost due to sickness) are 4.74, 4.79, 5.08, and 4.75, for 1993-1996, respectively, 4.19, 4.13 for 1997 and 1998, and 4.27 and 4.22 for the years 2000 and 2001, respectively. These absence rates, which refer to the population of workers covered by public health insurance (which is the vast majority), correspond to what we observe in the GSOEP data (based on 253 working days and on all workers: 4.99, 5.06, and 4.78 percent in 1993, 1994 and 1995, respectively. Then during the reform these shares are 4.20 and 4.64 percent in 1997 and 1998 and after the reform 4.39 and 
As illustrated in the upper part of Figure 1, the average number of days absent differs between treatment (not covered by a collective agreement) and control (covered workers) groups, indicating that the former generally report fewer days of absence. This finding holds true before, during and after the reform, except for workers under 40 following repeal (see the lower part of Fig. 1). Nevertheless, the raw means also suggest that the reform did have an effect on absence. That is, whereas the absence gap between treated and control observations prior to the reform was -3.4 days ( 8.8 days for workers without coverage and 12.2 days for covered workers), this gap widened to -4.7 days during the reform years only to shrink again to -2.0 days after its repeal. The rise and fall of this gap between treated and control observations is even more pronounced when the analytical focus shifts to younger workers. As the lower part of the figure illustrates, younger workers (below 55 or 40 years of age) seem to have reacted more strongly to the reform. For treated workers younger than 55 years of age, the average number of days absent decreased from 8.1 to 6.4 days during the reform period but rose to 9.3 days following repeal. The change in the gap between treated and control observations is even more pronounced, moving from -3.3 pre-treatment to -5.6 during treatment and down to -1.4 after treatment (repeal). For workers younger than 40 , these averages are $-2.5,-4.3$ and +0.9 , respectively.

Although these numbers represent raw gaps that do not take observed or unobserved heterogeneity into account, they nevertheless suggest that the reform did have an effect on workers, especially those younger than 55 years of age. Older workers, in contrast, are likely to be less credit constrained and may thus be less sensitive to reduced sick pay. Their absence may also be more strongly driven by genuine health concerns and hence less influenced by financial incentives. We therefore conduct an analysis of the treatment effects for all workers (aged 20 to 64) and then examine restricted age groups.

4.29 percent in 1999 and 2000, respectively. So despite the slightly different populations, the GSOEP and the Ministry of Health data seem to indicate similar absence rates. 
As Table 1 shows, treatment and control groups not only differ systematically in their average number of days absent but also in other characteristics. For instance, the treatment group earns lower hourly wages than the control group (by between 4 and $9 \%$, depending on the period considered). ${ }^{10}$ Moreover, although both groups have roughly the same average age, gender, civil status and health indicators, the treatment group is somewhat more educated and somewhat less likely to be blue collar or work part time. ${ }^{11}$ However, the most striking differences between the treatment and control groups are in terms of tenure, firm size, industry and civil service status. That is, workers without collective bargaining coverage (the treatment group) have lower tenure; work in smaller firms; are much more likely to work in services like trade, real estate and business activities; and are generally no civil servants. ${ }^{12}$ These differences between the two groups persist across the observation period: there are no major compositional changes between the covered and uncovered groups across time. Nevertheless, the regression analysis reported below controls for any compositional changes related to observed or time-constant unobserved characteristics.

Table 2 displays the distribution of the outcome variable, the annual number of days a worker was absent from work. In almost all periods, the 4th decile of the absence days' distribution is 0 or 1 , meaning that almost half the workers are not absent from work for a single day. Moreover, even though the median number of days absent is 2 in the treatment group and 4 or 5 among the controls, the distribution is highly skewed to the left with the 7 th

\footnotetext{
${ }^{10}$ Based on the assumption that reduced sick pay might lead to lower (efficiency) wages and thus might have both a direct effect on absence and an indirect effect through the wage rate, we estimated the effects of the sick pay reform on regular wages using standard difference-in-differences models with control variables and fixed-effect estimates. However, contrary to what efficiency wage theory might predict, all estimates of wage effects are insignificant, with most point estimates positive. This observation is consistent with experimental evidence in Dürsch, Oechsller and Vadovic (2008) who find barely any effort response by workers to sick pay. In our study, both these results support the interpretation that changes in the raw wage gap between treatment and control groups can be explained by compositional effects.

${ }^{11}$ Detailed information on the variables contained in the GSOEP is provided in Haisken-DeNew and Frick (2001).

12 Treated observations indicating that the individual is a civil servant most probably represent classification error in the civil service or the collective bargaining status in the original GSOEP data. The coding error affects only 2 percent of the sample assigned "treatment" status. We remain conservative by keeping the data as they are, because if these observations were in fact controls, this classification error would generate attenuation bias.
} 
decile between 6 and 12 days, the 9th decile between 20 and 30 days and the 99th percentile at 98 or more days. Thus, our estimation strategy must take into account the heavy censoring of the outcome distribution at zero.

\section{Effects of the Sick Pay Reform on Absence from Work}

We begin by estimating linear difference-in-differences models with the following specification:

$$
\text { absence }_{i t}=\alpha+\beta_{1} X_{i t}+\beta_{2} \text { reform }_{t}+\beta_{3} \text { nocoverage }_{i}+\tau\left(\text { reform }_{t} \times \text { nocoverage }_{i}\right)+\varepsilon_{i t}
$$

where absence denotes the number of days of absence and reform is a dummy variable indicating the time period during which the reduced sick pay reform was in place (1997 and 1998 ) and valued at zero pre-reform and post-repeal. Likewise, nocoverage is a dummy variable indicating that a worker was not covered by a collective bargaining contract (the treatment group). This nocoverage indicator controls for differences in absence rates between the treatment and control groups, which in the absence of any reform are assumed to be constant across time (the identifying assumption of the difference-in-differences estimator).

Time-specific variations in absence affecting both groups similarly are controlled for by the reform dummy as well as further time effects. ${ }^{13}$ The difference-in-differences estimator is given by $\tau$, which indicates the change in the absence differential between treatment and control groups after sick pay was reduced from 100 to $80 \%$. Specification (1) includes no control variables. However, specifications (2)-(4) stepwise add control variables

\footnotetext{
${ }^{13}$ These time effects control for macro shocks as long as these affect treatment and control groups similarly. Separate time effects for treatment and control groups would make the treatment effect unidentified. However, because treatment and control groups are distributed differently across industries, we could allow for industry-specific time and treatment effects and thereby allow for different effects of the macroeconomy on treatment and control groups. Because sample sizes shrink too much to estimate the industry-specific effects precisely, we have compared the average treatment effects on the treated, obtained as a weighted average of industry-specific treatment effects, with the main estimates reported in this paper. The differences in the point estimates were mostly minor.
} 
to allow for compositional changes in the two groups across time and improve the efficiency of the difference-in-differences estimator as long as they can be regarded as exogenous. The first group of variables, included in specification (2), are the regional unemployment rate, the log hourly wage, age, civil status (married, children), gender and some interactions between them. We employ these standard controls from the absence literature because of their likely impact on the incidence of sickness through their effect on the benefits and costs of shirking through absence. Specification (3) then integrates a further set of controls by including education, citizenship, and job and firm characteristics, as well as a dummy for West Germany (see Table 1 for details). The full specification (4) adds a last set of controls that refer to "health at present" and "satisfaction with health" as asked in the GSOEP. If respondents answer these health-related questions truthfully irrespective of their potential shirking behavior and if the reform had no impact on health (see Section 5), these variables are valid controls; otherwise, they are endogenous.

Table 3 shows the results for the OLS difference-in-differences estimator when both the pre-reform and post-repeal period are simultaneously included as the reference period (here and in the following, we use robust standard errors clustered at the person level). Hence, this phase of the analysis does not distinguish between the reform's switch-on and switch-off effects but rather compares the difference between the treatment and control groups during the reform with that before or after its repeal. This approach increases the sample size and hence the precision of the estimates.

To check the sensitivity of the estimates with respect to the control variables just described (the coefficients of the control variables are reported in Table A3 in the Appendix), in Table 3, we report the estimated treatment effects for specification (1) through (4). In this table, we also report the marginal effects at the mean of the difference-in-differences estimates of a count-data model, which is expected to fit the data better because of the dependent variable's count nature. We use the negative binomial model, NEGBIN, where the 
right hand side index of equation (1) enters an exponential function to model the expected value of absence days; for an application in the context of absence, see Winkelmann (1999); technical descriptions of the NEGBIN II model that we apply here can be found in Cameron and Trivedi (1998, p. 70ff.) or Winkelmann (2008, p.134ff.); nonlinear difference-indifferences models are discussed in Athey and Imbens (2006). The parameters reported here are the incremental effects of the treatment indicator (the interaction term) at the data mean. ${ }^{14}$

However, because the restriction of the sample to firm stayers may cause systematic attrition not only based on observed characteristics (which we control for in the OLS and NEGBIN estimates) but also based on unobserved characteristics, we control for unobserved heterogeneity by reporting (linear) fixed-effects estimates. More specifically, we identify the policy reform effect using only the "within individual variation", because the fixed-effects estimator effectively assesses the response to the reform by considering only treated and control individuals observed both during the reform and in a period without reform.

In terms of the estimate's sensitivity to the inclusion of control variables, controlling for compositional changes matters mostly for the estimated standard errors (and hence the statistical significance of the estimates). The point estimates are rather similar across specifications. Therefore, below we report estimates from the full specification (4) that have lower standard errors.

As regards the different modeling strategies, the differences in the point estimates between OLS and NEGBIN are minor, meaning that despite its theoretical deficiencies, the OLS model seemingly provides a very good approximation of the treatment effect at the mean. However, not surprisingly, most standard errors are somewhat smaller in the NEGBIN model, which is tailored to fit the count data. In addition, even though both the OLS and NEGBIN models suggest that the decrease in sick pay reduced the number of absence days

\footnotetext{
${ }^{14} \mathrm{Ai}$ and Norton (2003) derive a correct presentation of the cross derivative and cross difference in nonlinear models with interaction terms. However, this cross difference is not equal to the treatment effect shown in Puhani (2008).
} 
per year by 2 , this effect is only statistically significant in the NEGBIN model. Once we control for unobserved heterogeneity in a (linear) fixed-effects model, the point estimate becomes somewhat smaller (and insignificant) with an estimated reduction of 1.2 days in specification (4). Given that for the treated group the mean number of days absent was 8.8 before the reform, this figure amounts to a reduction in absence of between 14 and 24 percent, which is sizable.

As hinted at in the previous section, based on the raw data, we might expect the effect of the reform to be higher among younger workers. Therefore, in Table 4, we provide the difference-in-differences estimates for the different age groups (here and subsequently, for full specification 4 with all control variables). We find that in all models, the point estimates become larger when older workers (aged 56-64) are excluded. More specifically, for the age group 20-55, the fixed-effects estimate shows a significant 2.4 reduction in days absent per year. For the further restricted age group 20-40, at 2.2 days, this reduction is somewhat smaller. We do not provide separate point estimates for older workers, because the precision of these estimates is too low (for the age group 56-64, the standard errors range between 4 and 6 days, so that all estimates are statistically insignificant; the point estimates even change sign). Similarly, if we estimate the effects separately for men and women, the estimates become too imprecise to reach firm conclusions on gender differences: point estimates are negative for both genders and there is no clear pattern for whom the point estimates are larger.

\subsection{Effects at different points of the distribution}

The skewed nature of the distribution of absence days, with a high probability mass at zero, raises the question of whether the reform had a larger effect on longer or on shorter durations of absence. To answer this question, we describe the reform's effect at different parts of the distribution by difference-in-differences quantile regressions (for a technical 
description see Athey and Imbens, 2006, p. 446f.; another application is Song and

Manchester, 2007; Koenker, 2005, Chapter 2, provides a general introduction to quantile regression). Quantile regression difference-in-differences implies stronger identifying assumptions than does OLS because we must assume that the differences in the distributions (not simply the differences in the means) between treatment and control groups would have remained constant in the absence of reform. Hence, in Table 5, we show difference-indifferences quantile estimates by decile, again for the three age groups sampled.

Theoretically, the OLS estimate is the mean of the coefficients at all quantiles; however, as the results show, up to the 4th decile, the effect is (virtually) zero. This finding is not surprising given that around $40 \%$ of all workers in the sample report not having been absent for a single day. The point estimates of the reform's effect on days absent then grow ever more negative with increasing deciles. For all workers (i.e., aged 20-64), by the 9th decile, the point estimate is a statistically significant 4.8 days reduction in absence. ${ }^{15}$ It should also be noted that the 9th decile of the number of days absent for the treatment group is 23 , which corresponds to a sizable reduction in absence of more than $20 \%$. In other words, the quantile regressions reveal that it is mainly absence durations of several weeks (cumulated over the year) that are reduced by the reform.

Once the sample is restricted to workers aged $20-55$ or $20-40$, we obtain statistical significance from the 7 th decile onwards, with 7 th decile estimates of -0.8 in both cases. Given that the 7th decile of absence days in the treatment group before the reform was 8 days, this figure constitutes a reduction of almost one tenth. The reduction becomes larger at higher deciles (both absolutely and relatively) for the group aged 20-55. In the 20-40 age group, the point estimates at the very high quantiles (95th and 98th) are the largest of all

\footnotetext{
${ }^{15}$ The displayed quantile regression estimates, obtained using the econometric software package Stata 10, take sampling weights into account. Standard errors reported for the quantile regressions do not allow for clustering; however, we find that block-bootstrapped standard errors that do take clustering into account differ little from the asymptotic standard errors ignoring clustering in an unweighted regression.
} 
quantiles but are statistically insignificant because of the large standard errors associated with the sensitivity to outliers of quantile regressions for extreme quantiles of the distribution.

In results not shown here both OLS and probit estimates cannot detect any effect of the reform on the incidence of absence (i.e. a binary indicator of whether a person has been absent for at least one day or not). This is in line with the quantile regression estimates which do not find any effect near the median of the days of absence distribution.

\subsection{Switch-on and switch-off effects}

Because our dataset includes information on absence before and during the reform and after its repeal, we can estimate the effect of the reduction in sick pay (switch on) separately from the subsequent repeal and increase in sick pay (switch off). Doing so has two advantages. First, the difference-in-differences approach used here relies on the identifying assumption that in the counterfactual absence of the reform, the gap in absence days between treatment and control groups would have remained constant. One reason for violating this assumption would be another incident or reform of which the researcher is unaware that might have had a differential impact on absence days for both groups. To dissipate such doubts, research designs that introduce and subsequently take back a reform are very helpful. If both effects have similar values and both indicate that absence is lower with lower sick pay, we can have more confidence that the effects estimated are genuinely caused by the sick pay reform.

In fact, the above-mentioned estimates do not distinguish between the pre-reform and post-repeal periods, which implies that the introduction of the reform has the same impact on absence (in absolute terms) as its repeal. To check this assumption, we estimate the effects of the reform's implementation (switch on) and repeal (switch off) separately. Table 6 presents the switch-on and switch-off estimates separately by age group based on data for the years 1994, 1995, 1997 and 1998 for the switch-on effects and for the years 1997, 1998, 1999 and 
2000 for the switch-off effects. Table 7 then reports the corresponding quantile regression estimates. The models are specified so that a negative estimate always implies that, as expected, absence is lower during the period of reduced sick pay.

In Table 6, all switch-on and switch-off point estimates are negative in absolute value. In the NEGBIN model, all coefficients are statistically significantly different from zero. Hence, we argue that the reform had a genuine effect on days absent. Interestingly, however, when we compare the absolute size of the switch-on and switch-off effects in Table 6, we find that in all cases (except for the age group 20-64 in the fixed-effects estimates) the switch-off point estimates are larger than the switch-on effects (this holds at virtually all quantiles, as shown in Table 7). However, this difference is only statistically significant in OLS specifications that neither take into account the count data nature of the outcome variable nor unobserved heterogeneity. In the NEGBIN model the point estimate is an insignificant 0.44 days larger for the switch-off effect compared to the switch-on effect, but this difference amounts only to insignificant 0.14 days in the fixed-effects model for workers aged 20-55. Because these differences are not statistically significant, one choice would be to ignore them; however, the difference becomes larger - albeit insignificant - for the 20-40 age group at 1.47 days (marginally insignificant at the 10 percent level) in the NEGBIN, and at 1.37 (insignificant) in the fixed-effects model.

One possible basis for interpreting these larger switch-off point estimates is the experimental and psychological literature on extrinsic versus intrinsic motivation. According to Pinder (2008, p. 81), intrinsic motivation, roughly defined, relates to "behavior that is performed for its own sake rather than for the purpose of acquiring any material or social rewards". The fact that the switch-off effects are larger than the switch-on effects is congruent with experimental evidence from Gächter, Kessler and Königstein (2007) that incentive contracts negatively impact voluntary cooperation among individuals, and that these negative effects persist even after the incentive contract is repealed. It also relates to an 
ongoing debate in the psychological literature on whether extrinsic motivation may crowd out intrinsic motivation (Pinder, 2008, p. 86ff.). That is, because sick pay before the reform was $100 \%$, showing up for work in Germany had an aspect of voluntary cooperation, at least for workers not seeking promotion, and such voluntary cooperation can be linked to intrinsic motivation. Reduced sick pay then added an element of immediate extrinsic motivation that was abolished after the reform was repealed. Hence, in light of Gächter, Kessler and Königstein's (2007) findings, the experience of extrinsic motivation may have crowded out some intrinsic motivation even after repeal. Nevertheless, the extrinsic motivation of reduced sick pay during the reform period was effective in reducing absence, which supports the economist's paradigm that people react to incentives.

\subsection{Placebo estimates and estimates by calendar year}

Because we have two years of observations for each "regime" (pre-reform, reform, after repeal), we can in theory test the identifying assumption of the difference-in-differences estimator by, for example, testing whether a "placebo treatment effect" estimate for the year 1995 (pre-reform) with 1994 as the base year (also pre-reform) is equal to zero. In Table 8, we therefore define 1994 as the base year and estimate "treatment effects" for all further years used in the previous estimates: 1995 (pre-reform), 1997, 1998 (both reform) and 1999, 2000 (both post-repeal). If the difference-in-differences identifying assumption is correct, only the grey-shaded coefficients (reform period) should be different from zero.

Table 8 shows that standard errors become very large when estimating treatment effects by calendar year (most standard errors are between 1 and 2 days, some are even larger), so that hardly any coefficient is statistically significant. Still, larger negative coefficients are (with few exceptions) observed mainly during the reform period. After the repeal of the reform, some point estimates turn quite large and positive, especially for the year 2000 (two of them even significant), but the standard errors are large as well. We cannot 
determine whether this finding is due to crowding out of intrinsic motivation as mentioned in the previous subsection or due to a violation of the identifying assumption. In general, we observe a clear decrease in absence with the onset of the reform period and a subsequent increase after the repeal of the reform. This holds both across the defined age group samples and across estimation methods (OLS, NEGBIN, and linear fixed-effects).

\section{Effects of the Sick Pay Reform on Other Health-Related Outcomes}

Although reduced sick pay decreased absence from work, it remains unclear whether this means that the reform was beneficial from a welfare perspective. In this section, we show that the reform surprisingly even reduced the average number of days spent in hospital. This suggests that at least part of the absence reduced by the reform was genuinely health related. However, we also show that the reform was not associated with a significant reduction in indicators of subjective health or long-term sickness. Taken together, the reform might have reduced inefficient use of the health care system.

According to the OECD, in 1995, just before the sick pay reform, health expenditure in Germany as a percentage of the GDP was 10.1\%, higher than in the U.K. (6.9\%) but lower than in the U.S. (13.3\%). Life expectancy at birth, however, was rather similar in these three countries (between 75.7 and 76.7 years). The number of doctor visits per year was highest in Germany (6.4), followed by the U.K. (6.1) and the U.S. (3.3); by 2003, these gaps had become even larger, at 7.6, 5.2 and 3.9, respectively. The average number of hospital stays per person was $0.18,0.21$ and 0.12 and the average length of stay for acute care was $11.4,7.1$ and 6.5 days for Germany, the U.K. and the U.S., with Germany having by far the longest average duration of acute care stays. Hence, contacts with the medical system are seemingly more frequent and longer in Germany. Because these OECD figures (for the whole population) correspond roughly to the sample means in the GSOEP (for a sample of workers aged 20-64), we consider three further outcome variables: the number of doctor visits in the 
last 3 months (asked in the GSOEP), number of days in hospital (including zeros) and number of hospital stays (see Table 9 for the sample distributions). We then go on to investigate the reform's effects on two subjective health indicators and an indicator for longterm sickness before we conclude by investigating the reform's effects on satisfaction with financial security in case of sickness.

\subsection{Effects on usage of the health care system}

In Table 10, we report difference-in-differences estimates for the three outcomes concerning usage of the health care system by age group. Not only are all point estimates negative, but those for number of days in hospital and number of hospital stays are all statistically significant. Moreover, the fixed-effects estimates for these two variables are similar to the OLS results, implying that the OLS findings are not driven by unobserved heterogeneity. Because of the extreme extent of censoring of the hospital visit outcome variables, we place special emphasis on the NEGBIN estimates. The NEGBIN point estimates are somewhat smaller in absolute value; however, they still remain economically and statistically significant. For the 20-64 age group, compared to a pre-reform treatment group average of 1.35 , the reform reduced the average number of days in hospital by 0.41 days (almost one third, 30\%) on average. Given that it also reduced the number of stays by an estimated $0.045(41 \%)$ at least part of the reduction in the number of days hospitalized is explained by the actual elimination of some hospital stays. Although these estimates may seem large, they can be made plausible by doctors' incentives given the low occupancy rates of hospital beds: these ranged between only 76 and 82\% in Germany in the period 1996 through 2006 (data from the German Hospital Society, Deutsche Krankenhaus Gesellschaft). 


\subsection{Effects on health indicators}

Given the reform's effects on absence from work and hospital stays, we ask whether the estimated reductions had a detrimental effect on health. Hence we use the two subjective health indicators asked in the GSOEP (Health At Present and Satisfaction With Health) as outcome variables. Subjective health measures have been critically discussed in the literature. On the one hand, economists usually postulate that each person should be the best judge of his or her utility and this may also be true for health (Dolan, 2000, p. 1732). In a literature survey, Idler and Benyamini (1997) find that "global self-rated health is an independent predictor of mortality in nearly all of the studies, despite the inclusion of numerous specific health status indicators" (p. 21). On the other hand, inter-person comparisons of self-rated health seem to be plagued by people's adaptation to changing states of health as well as changing reference groups over the life cycle and with changing health (Groot, 2000).

In addition to subjective health, we check whether the reform had an impact on the incidence of continuous sickness spells lasting for at least six weeks. This is the only indicator in the GSOEP that we could find as an objective proxy for serious illness. The subjective health measures are recorded on Likert scales and have been normed to range between 0 and 1 . Control variables are the same as in specification (3) of Table 3. We report OLS and fixed-effects estimates, for the whole sampling period and separately for switch-on and switch-off effects. The reform's effects on the subjective health indicators are presented in Table $11 .^{16}$

In the table, most of the estimates are statistically insignificant. For Health At Present, two of the switch-off fixed effects estimates are negative and statistically significant at the 10 percent level. However, neither the corresponding estimates for Satisfaction With Health nor

\footnotetext{
${ }^{16}$ We use the same sample as for the estimation of the reform's effects on absence. Hence, in order to be in the sample, a person has to have valid responses in the current and in the consecutive year. The reason is that the information on absence is obtained from retrospective information in the following year's GSOEP questionnaire. Our sample definitions guarantee that the estimates of absence and health effects refer to the same population.
} 
the corresponding switch-on estimates are statistically significant. For Satisfaction With Health as the outcome, three of the nine OLS estimates are statistically significant and negative, but none of the fixed-effects estimates is statistically significant. Hence, from these estimates, there is no convincing evidence that the sick pay reform had a negative effect on subjective health.

Nevertheless, health may be deteriorating over time: in Table 11, we have considered subjective health in the current year (1997 and 1998 for the reform years). In Table 12 we investigate whether the reform had an impact on subjective health a year later (so the outcomes for the reform years are measured in 1998 and 1999; for the control years, we also lag the outcomes by one year accordingly). As the table shows, all point estimates are close to zero and none of them is statistically significant. Hence, when considering subjective health indicators for all employees, either in the current or in the following year, there is no robust evidence for the reform to have had any significantly negative effects.

Because the population of employees consists of a lot of people who have not been sick during the entire year, we narrow down the population of interest in the following: first, we consider the reform's effects on subjective health only on employees who state to have visited the doctor at least once during the previous three months (i.e. people who experienced some sort of sickness). Second, we restrict the sample further by considering only employees who have been in hospital during the current year. We then estimate the reform's effects on subjective health for these subpopulations. Again, we distinguish between the effects on subjective health in the current year and between effects on subjective health in the subsequent year to capture any potentially protracted effects. The results for workers who have been to the doctor are presented in Table 13 and Table 14 and those for workers who have been to hospital in Table 15 and Table 16, respectively. As can be seen from Table 13 and Table 14, there is no convincing indication that the sick pay reform decreased subjective health outcomes either in the current or in the following year. There is one negative and 
statistically significant (at the 10 percent level) coefficient in the fixed effects model: the switch-off effect for the age group 20-40 in the estimate for Health At Present. However, the corresponding estimate for Satisfaction With Health is statistically insignificant. The two OLS estimates which are negative and statistically significant at the 10 percent level in Table 13 are close to zero and statistically insignificant when a fixed-effects model is estimated. The one statistically significant fixed-effects estimate in Table 14 (effect on Health At Present in the following year) is positive instead of negative and insignificant in the corresponding estimate for Satisfaction With Health as the outcome. When we restrict the sample to workers who have been in hospital (see Table 15 and Table 16), there are again no statistically significant negative effects on subjective health. ${ }^{17}$

To investigate at least a proxy for an objective health outcome in the GSOEP, we use the question on a continuous sickness spell of 6 weeks or longer. The way this question will be understood by most Germans is referring to being sick as declared by a physician, because for sickness spells longer than 2 days, employees have to provide a doctor's certificate. Note that although we have already shown in the previous section that the reform predominantly reduced longer durations of absence, as demonstrated by the quantile regression estimates, longer duration there meant longer days of absence accumulated over a calendar year, that is, a long duration of absence might be an accumulation of many shorter spells. Here, we look at a continuous sickness spell of at least 6 weeks. As Table 17 shows, the sick pay reform seems to have decreased, not increased the incidence of long and continuous sickness spells. The estimates indicate a 2 to 3 percentage point reduction in long-term sickness due to the reform and they are statistically significant. One explanation for the reduced incidence of long-term

\footnotetext{
${ }^{17}$ Note that in these estimates, the number of observations who are treated during the reform years is reduced to only 22 to 63 workers (depending on the age group considered). This may explain why there is a positive and fairly large estimate of the reform for the age group 20-40 in Table 17. We report no fixed-effects estimates for this age group, because we would only have 10 persons in the treatment group during the treatment period with a within variation in the treatment status that is needed to identify the fixed-effects estimate. For the age group 20-64, inference in the fixed effects estimates is also plagued by the low number of persons with a within variation in the treatment indicator, which is 26 in this case.
} 
sickness may again be the incentive effects provided by the reform that seem to have dominated any potentially negative effects on health. To investigate the possibility of negative health effects further, we check whether the incidence of long continuous sickness spells was increased with a delay of one year: these estimates are provided in the lower panel of Table 17. Only one of the estimates is statistically significant using OLS (again suggestion a reduction in long-term sickness), whereas the corresponding fixed-effects estimate is virtually zero and statistically insignificant. All other point estimates are also close to zero and statistically insignificant.

Hence, we conclude that there is no convincing evidence that the sick pay reform impaired health outcomes, despite of the fact that it reduced stays in hospital.

\subsection{Effects on the perception of liquidity constraints in case of sickness}

As a last check, we estimate whether the reform changed the employee's "satisfaction with their financial security in the case of sickness". Again, this question was asked on a Likert scale in the GSOEP, which we normalize between 0 (very bad) and 1 (very good). During our observation period, this question was only asked in 1997 and 2002, so that we only provide switch-off estimates. The results are presented in Table 18. For all workers and for the restricted sample of workers who have visited the doctor in the last three months at least once, none of the point estimates is statistically significant and all point estimates are small. If we restrict the sample further to workers who have been to hospital in the current year, the number of treated persons in the treatment period becomes very small: there are only 59,49 , and 22 such persons for the OLS estimates and only 3,3 , and 1 person with a within variation in the treatment indicator for the age groups 20-64, 20-55 and 20-40, respectively, so that we do not report fixed-effects estimates. We are also cautions in interpreting the estimates based on 59, 49, and 22 treated persons in the sample of people who have been to hospital for the age groups 20-64, 20-55 and 20-40, respectively, and 
conclude that at least from the sample of people who have been to the doctor as well as for all workers, we cannot find any evidence for negative effects of the reform on the satisfaction with financial security in case of sickness.

\section{Conclusions}

The economic costs of absence from work can be influenced by economic policy. For example, in contrast to the cases of Switzerland, the U.K. or the U.S., German federal law (as well as statutes in other continental European countries) dictates that employees receive $100 \%$ of their wages as sick pay from day 1 of their absence spell. However, whereas the literature to date does suggest that such absence is influenced by economic incentives like wages, local unemployment, probationary periods or sick pay, few studies estimate the effects of sick pay on absence by way of natural experiments. Moreover, to the best of our knowledge, ours is the first study to analyze health-related outcomes of sick pay reform and also the first to estimate both the switch-on and switch-off effects; that is, the effects of the reform's implementation and its subsequent repeal by a changed federal government.

The basis of our empirical strategy is a difference-in-differences approach that controls for time and group effects. In some specifications, we also control for unobserved individual heterogeneity by explicitly using the panel nature of the data in a fixed-effects estimation. Overall, we estimate that the reduction in sick pay from $100 \%$ of the wage to $80 \%$ decreased absence days by about 2 days per annum on average, which is equal to about one percent of annual working days in Germany (about half the difference between U.S. and German absence rates). As our quantile regressions find, this reduction is primarily driven by a shortening of very long spells. These results are confirmed by separate estimates for switchon and switch-off effects. Our finding is significant in that if labor contributes two-thirds of the GDP, then the ceteris paribus effect of the reform amounts to an increase in the GDP of about two thirds of a percent through the reduction of absence from work alone. 
Besides reducing absence from work, decreased sick pay also reduces reliance on the health care system, which in Germany has almost zero marginal cost to most individuals (the system is mostly public). We find that the reduction in absence due to the reform (by about 2 days) also reduces the average number of days spent in hospital (by not quite half a day, a reduction of 30\%). Data from the German Hospital Society (Deutsche Krankenhaus Gesellschaft) report hospital costs as a percent of GDP at a fairly steady $2.4 \%$. This would imply that the sick pay reform had saved $0.72 \%$ of GDP through hospital costs alone, and in addition to the two thirds of GDP saved for employers. In sum, the reform might have saved up to $1.38 \%$ of GDP. Although costs saved might be lower if the reduction in absence and hospital stays referred to less than average productivity days at work and less than average costs per day in hospital, even half a percent of GDP saved would be sizable. The policy relevance of these results is reinforced by the fact that we did not find any remarkable effects of the reform on subjective health indicators nor on long-term sickness, indicating that the reform might have reduced the inefficient use of the medical system. 


\section{References}

Ai, C., Norton, E.C. 2003. Interaction terms in logit and probit models. Economics Letters $80,123-129$.

Athey, S., Imbens, G. 2006. Identification and inference on nonlinear difference-indifferences models. Econometrica 74, 431-497.

Auer, P., Cazes, S. 2000. The resilience of the long-term employment relationship: Evidence from the industrialized countries. International Labour Review 139, 379-408.

Bispinck, R., WSI-Tarifarchiv. 1997. Entgeltfortzahlung im Krankheitsfall, Eine tarifpolitische Bilanz ein Jahr nach der gesetzlichen Neuregelung [Sick pay: Taking stock from a collective bargaining perspective one year after the new law]. Elemente Qualitativer Tarifpolitik No. 31, WSI Informationen zur Tarifpolitik, Düsseldorf.

Black, D., Daniel, K., Sanders, S. 2002. The impact of economic conditions on participation in disability programs: Evidence from the coal boom and bust. American Economic Review 92, 27-50.

Bound, J., Brown, Ch., Mathiowetz, N. 2001. Measurement Error in Survey Data. In Heckman, J.J., Leamer, E. (eds.) Handbook of Econometrics Vol. 5, Amsterdam: Elsevier.

Bundesministerium der Justiz [Federal Ministry of Justice]. 1996. Bundesgesetzblatt, Teil I [Federal Law Journal, Part I], No. 55, Bundesanzeiger Verlagsgesellschaft, Bonn.

Bundesministerium der Justiz [Federal Ministry of Justice:]. 2003. Gesetz über die Zahlung des Arbeitsentgelts an Feiertagen und im Krankheitsfall (Entgeltfortzahlungsgesetz) [Law on Payment on Public Holidays and in the Case of Sickness (the Continuation of Pay Act)]. Retrieved January 29, 2009 from http://www.gesetze-iminternet.de/bundesrecht/entgfg/gesamt.pdf

Bundesministerium der Justiz [Federal Ministry of Justice]. 2008. Sozialgesetzbuch (SGB) Fünftes Buch (V) [Social Law, Book 5]. Retrieved January 29, 2009 from http://www.gesetze-im-internet.de/bundesrecht/sgb_5/gesamt.pdf

Cameron, A.C., Trivedi, P.K. 1998. Regression Analysis of Count Data. Cambridge University Press, Cambridge.

Campolieti, M. 2004. Disability insurance benefits and labor supply: Some additional evidence. Journal of Labor Economics 22, 863-889.

Clemens, H., Scheuring, O. Steingen, W. Wiese, F. 2006. Kommentar zum BundesAngestelltentarifvertrag (BAT) [Comment on the collective bargaining contract of federal employees]. R. Boorberg Verlag, Edition Moll.

Deutscher Bundestag [German Parliament]. 1998. Drucksache 14/45 (circular). Available at http://dip.bundestag.de/btd/14/000/1400045.pdf

Dolan, P. 2000. The Measurement of Health-Related Quality of Life for Use in Resource Allocation Decisions in Health Care, in A. Culyer and J.P. Newhouse (eds.): Handbook of Health Economics, Vol. 1B, Amsterdam: Elsevier. 
Dürsch, P., Oechssler, J., Vadovic, R. 2008. Sick pay provision in experimental labor markets. Discussion Paper No. 476, University of Heidelberg.

Gächter, S., Kessler, E., Königstein, M. 2007. Performance incentives and the dynamics of voluntary cooperation (mimeograph), University of Nottingham.

Groot, W. 2000. Adaptation and Scale of Reference Bias in Self-Assessments of Quality of Life. Journal of Health Economics 19, 403-420.

Gruber, J. 2000. Disability insurance benefits and labor supply. Journal of Political Economy 108, 1162-1183.

Haisken-DeNew J.P., Frick, J.R. 2001. DTC Desktop Companion to the German SocioEconomic Panel Study (SOEP), available at http://www.diw.de/documents/dokumentenarchiv/17/diw_01.c.38951.de/dtc.409713 .pdf

Henrekson, M., Persson, M. 2004. The effects on sick leave of changes in the sickness insurance system. Journal of Labor Economics 22, 87-113.

Ichino, A., Riphahn, R.T. 2005. The effect of employment protection on worker effort: Absenteeism during and after probation. Journal of the European Economic Association 3, 120-143.

Idler, E.L., Benyamini, A. 1997. Self-Rated Health and Mortality: A Review of TwentySeven Community Studies, Journal of Health and Social Behavior 38, 21-37.

Johansson, P., Palme, M. 2002. Assessing the effect of public policy on worker absenteeism. Journal of Human Resources 37, 381-409.

Johansson, P., Palme, M. 2005. Moral hazard and sickness insurance. Journal of Public Economics 89, 1879-1890.

Johnson, W.G., Ondrich, J. 1990. The Duration of Post-Injury Absences from Work. Review of Economics and Statistics 72, 578-586.

Koenker, R. 2005. Quantile Regression. Cambridge University Press, Cambridge.

Kreider, B., Riphahn, R.T. 2000. Explaining Applications to the U.S. Disability System, Journal of Human Resources 35, 82-115.

Meyer, B.D., Viscuse, W.K., Durbin, D.L. 1995. Workers' compensation and injury duration: Evidence from a natural experiment. American Economic Review 85, 322340.

Neuhauser, F., Raphael S. 2004. The effect of an increase in worker's compensation benefits on the duration and frequency of benefit receipt. Review of Economics and Statistics $86,288-302$.

Pinder, C.C. 2008. Work Motivation in Organizational Behavior, 2nd edition. Psychology Press, New York.

Puhani, P.A. 2008. The treatment effect, the cross difference, and the interaction term in nonlinear "difference-in-differences" models. IZA Discussion Paper No. 3478, Bonn. 
Osterkamp, R. 2002. Dice Reports: Work lost due to illness - An international comparison. CESifo Forum 4/2002, 36-40.

Riphahn, R.T. 2004. Employment protection and effort among German employees. Economics Letters 85, 353-357.

Riphahn, R.T., Thalmaier, A. 2001. Behavioural effects of probation periods: An analysis of worker absenteeism. Jahrbücher für Nationalökonomie und Statistik 221, 178-201.

Schmitt, J. 2005. Entgeltfortzahlungsgesetz, Kommentar [The Continuation of Pay Act: Commentary]. Verlag C.H. Beck, Munich.

Song, J.G., Manchester, J. 2007. New evidence on earnings and benefit claims following changes in the Retirement Earnings Test in 2000. Journal of Public Economics 91, $669-700$.

Winkelmann, R. 1999. Wages, firm size and absenteeism. Applied Economic Letters 6, 337 341.

Winkelmann, R. 2008. Econometric Analysis of Count Data. $5^{\text {th }}$ edition. Springer Verlag, Heidelberg. 
Table 1

Sample means by year and treatment status

\begin{tabular}{|c|c|c|c|c|c|c|}
\hline & \multicolumn{3}{|c|}{ Treated } & \multicolumn{3}{|c|}{ Control } \\
\hline & $1994 / 95$ & $1997 / 98$ & $1999 / 00$ & $1994 / 95$ & $1997 / 98$ & $1999 / 00$ \\
\hline Days absent & 8.8 & 8.0 & 9.7 & 12.2 & 12.7 & 11.7 \\
\hline Hourly wage & 2.47 & 2.65 & 2.65 & 2.56 & 2.69 & 2.70 \\
\hline Regional unemployment rate & 10.6 & 12.6 & 11.3 & 10.4 & 12.4 & 11.3 \\
\hline \multicolumn{7}{|l|}{ Civil status indicators } \\
\hline Age & 38.8 & 42.9 & 41.6 & 40.5 & 43.5 & 42.7 \\
\hline Married & 0.60 & 0.64 & 0.57 & 0.63 & 0.68 & 0.65 \\
\hline Female & 0.44 & 0.45 & 0.48 & 0.42 & 0.42 & 0.41 \\
\hline Children younger than 16 & 0.38 & 0.35 & 0.35 & 0.37 & 0.35 & 0.34 \\
\hline Female $\times$ children younger than 16 & 0.15 & 0.16 & 0.16 & 0.14 & 0.12 & 0.11 \\
\hline Female $\times$ married & 0.25 & 0.28 & 0.26 & 0.25 & 0.27 & 0.26 \\
\hline \multicolumn{7}{|l|}{ Educational attainment } \\
\hline Higher education - University degree & 0.13 & 0.14 & 0.20 & 0.12 & 0.12 & 0.15 \\
\hline Higher education - no degree & 0.21 & 0.19 & 0.22 & 0.24 & 0.26 & 0.26 \\
\hline Apprenticeship & 0.53 & 0.54 & 0.48 & 0.48 & 0.48 & 0.46 \\
\hline No apprenticeship & 0.13 & 0.12 & 0.11 & 0.15 & 0.15 & 0.13 \\
\hline \multicolumn{7}{|l|}{ Job and firm characteristics } \\
\hline Temporary work contract & 0.04 & 0.02 & 0.06 & 0.06 & 0.03 & 0.05 \\
\hline Working fulltime & 0.80 & 0.81 & 0.79 & 0.85 & 0.86 & 0.85 \\
\hline Blue-collar worker & 0.32 & 0.26 & 0.28 & 0.38 & 0.37 & 0.35 \\
\hline White-collar worker & 0.67 & 0.72 & 0.70 & 0.50 & 0.51 & 0.54 \\
\hline Civil servant & 0.02 & 0.01 & 0.02 & 0.12 & 0.12 & 0.11 \\
\hline \multicolumn{7}{|l|}{ Citizenship/region } \\
\hline German & 0.92 & 0.93 & 0.94 & 0.92 & 0.91 & 0.91 \\
\hline West Germany & 0.77 & 0.79 & 0.80 & 0.82 & 0.82 & 0.82 \\
\hline \multicolumn{7}{|l|}{ Firm size } \\
\hline Firm size (1-19) & 0.41 & 0.40 & 0.34 & 0.14 & 0.12 & 0.14 \\
\hline Firm size (20-199) & 0.32 & 0.35 & 0.31 & 0.28 & 0.29 & 0.28 \\
\hline Firm size $(200-1,999)$ & 0.15 & 0.14 & 0.19 & 0.26 & 0.27 & 0.27 \\
\hline Firm size $(>2,000)$ & 0.12 & 0.11 & 0.15 & 0.32 & 0.32 & 0.30 \\
\hline \multicolumn{7}{|l|}{ Tenure } \\
\hline Tenure (<1 year) & 0.06 & 0.00 & 0.17 & 0.03 & 0.00 & 0.08 \\
\hline Tenure (1-3 years) & 0.31 & 0.06 & 0.20 & 0.16 & 0.04 & 0.09 \\
\hline Tenure ( $3-5$ years) & 0.18 & 0.20 & 0.11 & 0.14 & 0.11 & 0.08 \\
\hline Tenure (5-10 years) & 0.19 & 0.37 & 0.25 & 0.21 & 0.31 & 0.25 \\
\hline Tenure (10-15 years) & 0.07 & 0.13 & 0.11 & 0.12 & 0.12 & 0.14 \\
\hline Tenure (15-20 years) & 0.06 & 0.06 & 0.06 & 0.11 & 0.13 & 0.12 \\
\hline Tenure (>20 years) & 0.12 & 0.18 & 0.11 & 0.23 & 0.29 & 0.24 \\
\hline \multicolumn{7}{|l|}{ Industry } \\
\hline Agriculture, hunting and forestry & 0.02 & 0.02 & 0.02 & 0.01 & 0.00 & 0.01 \\
\hline Mining and quarrying & 0.00 & 0.00 & 0.00 & 0.01 & 0.00 & 0.00 \\
\hline Manufacturing & 0.29 & 0.32 & 0.28 & 0.29 & 0.31 & 0.30 \\
\hline Electricity, gas and water supply & 0.01 & 0.00 & 0.01 & 0.02 & 0.02 & 0.02 \\
\hline Construction & 0.10 & 0.08 & 0.06 & 0.08 & 0.06 & 0.06 \\
\hline Wholesale and retail trade & 0.24 & 0.21 & 0.23 & 0.11 & 0.09 & 0.10 \\
\hline Transport and communication & 0.04 & 0.03 & 0.03 & 0.07 & 0.06 & 0.05 \\
\hline Financial intermediation & 0.03 & 0.04 & 0.05 & 0.04 & 0.05 & 0.05 \\
\hline Real estate and business activities & 0.14 & 0.18 & 0.19 & 0.03 & 0.02 & 0.04 \\
\hline Public administration and defense & 0.02 & 0.01 & 0.02 & 0.14 & 0.15 & 0.15 \\
\hline Education & 0.01 & 0.01 & 0.02 & 0.07 & 0.08 & 0.06 \\
\hline
\end{tabular}


Table 1 (continued)

Sample means by year and treatment status

\begin{tabular}{|c|c|c|c|c|c|c|}
\hline & \multicolumn{3}{|c|}{ Treated } & \multicolumn{3}{|c|}{ Control } \\
\hline & $1994 / 95$ & $1997 / 98$ & $1999 / 00$ & $1994 / 95$ & $1997 / 98$ & $1999 / 00$ \\
\hline \multicolumn{7}{|l|}{ Industry } \\
\hline Health and social work & 0.06 & 0.05 & 0.07 & 0.11 & 0.11 & 0.12 \\
\hline Other social and personal service & 0.04 & 0.04 & 0.03 & 0.03 & 0.04 & 0.04 \\
\hline \multicolumn{7}{|l|}{ Satisfaction with health } \\
\hline Very poor & 0.01 & 0.01 & 0.00 & 0.01 & 0.01 & 0.01 \\
\hline Poor & 0.06 & 0.09 & 0.09 & 0.07 & 0.06 & 0.07 \\
\hline Satisfactory & 0.27 & 0.31 & 0.26 & 0.28 & 0.30 & 0.30 \\
\hline Good & 0.45 & 0.45 & 0.48 & 0.44 & 0.47 & 0.45 \\
\hline Very good & 0.21 & 0.14 & 0.17 & 0.20 & 0.16 & 0.17 \\
\hline \multicolumn{7}{|l|}{ Health at present } \\
\hline Very poor & 0.01 & 0.01 & 0.01 & 0.01 & 0.01 & 0.01 \\
\hline Poor & 0.10 & 0.13 & 0.12 & 0.11 & 0.10 & 0.11 \\
\hline Satisfactory & 0.32 & 0.34 & 0.32 & 0.31 & 0.34 & 0.36 \\
\hline Good & 0.49 & 0.44 & 0.45 & 0.47 & 0.47 & 0.45 \\
\hline Very good & 0.08 & 0.08 & 0.10 & 0.10 & 0.08 & 0.07 \\
\hline$n$ & 2,227 & 1,056 & 1,620 & 8,024 & 5,044 & 5,731 \\
\hline
\end{tabular}

Source: German Socio-Economic Panel (GSOEP), own calculations.

Table 2

Percentiles of absence days by period and treatment status

\begin{tabular}{|c|c|c|c|c|c|c|}
\hline \multirow[b]{2}{*}{ Percentile } & \multicolumn{2}{|c|}{$\begin{array}{l}1994 \text { / } 1995 \\
\text { (Pre-reform) }\end{array}$} & \multicolumn{2}{|c|}{$\begin{array}{c}1997 \text { / } 1998 \\
\text { (Treatment Period) }\end{array}$} & \multicolumn{2}{|c|}{$\begin{array}{c}1999 \text { / } 2000 \\
\text { (Repeal) }\end{array}$} \\
\hline & $\begin{array}{c}\text { Treated } \\
\text { (no coll. } \\
\text { agreement) }\end{array}$ & $\begin{array}{c}\text { Control } \\
\text { (coll. } \\
\text { agreement) }\end{array}$ & $\begin{array}{c}\text { Treated } \\
\text { (no coll. } \\
\text { agreement) }\end{array}$ & $\begin{array}{c}\text { Control } \\
\text { (coll. } \\
\text { agreement) }\end{array}$ & $\begin{array}{c}\text { Treated } \\
\text { (no coll. } \\
\text { agreement) }\end{array}$ & $\begin{array}{c}\text { Control } \\
\text { (coll. } \\
\text { agreement) }\end{array}$ \\
\hline 30 & 0 & 0 & 0 & 0 & 0 & 0 \\
\hline 40 & 0 & 1 & 0 & 0 & 0 & 1 \\
\hline 50 & 2 & 5 & 2 & 4 & 2 & 4 \\
\hline 60 & 5 & 8 & 4 & 7 & 5 & 6 \\
\hline 70 & 8 & 12 & 6 & 10 & 8 & 10 \\
\hline 80 & 14 & 16 & 10 & 15 & 12 & 15 \\
\hline 90 & 23 & 30 & 20 & 30 & 21 & 28 \\
\hline 95 & 40 & 49 & 30 & 50 & 36 & 44 \\
\hline 96 & 42 & 60 & 30 & 60 & 42 & 53 \\
\hline 97 & 51 & 65 & 40 & 75 & 52 & 64 \\
\hline 98 & 65 & 90 & 50 & 110 & 80 & 90 \\
\hline 99 & 105 & 125 & 98 & 165 & 117 & 124 \\
\hline 100 & 210 & 365 & 365 & 365 & 365 & 365 \\
\hline Mean & 8.8 & 12.2 & 8.0 & 12.7 & 9.7 & 11.7 \\
\hline$n$ & 2,227 & 8,024 & 1,056 & 5,044 & 1,620 & 5,731 \\
\hline
\end{tabular}

Source: German Socio-Economic Panel (GSOEP), own calculations. 
Table 3

Difference-in-differences estimates

\begin{tabular}{lccc}
\hline & OLS & NEGBIN & FE \\
\hline \hline & & & \\
Specification (1) & -1.82 & -1.97 & -1.19 \\
(s.e.) & $(1.44)$ & $(1.50)$ & $(1.27)$ \\
Specification (2) & -1.92 & -2.07 & -1.18 \\
(s.e.) & $(1.42)$ & $(1.28)$ & $(1.25)$ \\
Specification (3) & -1.74 & $-1.94^{*}$ & -1.28 \\
(s.e.) & $(1.37)$ & $(1.11)$ & $(1.24)$ \\
Specification (4) & -1.99 & $-2.07^{* *}$ & -1.24 \\
(s.e.) & $(1.33)$ & $(0.91)$ & $(1.22)$ \\
\hline & 23,702 & 23,702 & 23,702 \\
\hline
\end{tabular}

Note: ${ }^{*},{ }^{* *}$ and ${ }^{* * *}$ denote significance at the $10 \%, 5 \%$ and $1 \%$ level, respectively. The specifications are distinguished by the set of control variables: specification (1) includes no controls; specification (2) adds state unemployment, log hourly wage, civil status indicators, gender and some interaction terms to account for compositional changes: specification (3) adds education, citizenship, job and firm characteristics, and a dummy for West Germany; specification (4) extends the set of control variables by adding reported health status and satisfaction with health.

Source: German Socio-Economic Panel (GSOEP), own calculations.

Table 4

Difference-in-differences estimates for restricted age groups

\begin{tabular}{lccc} 
& OLS & NEGBIN & $\mathrm{FE}$ \\
\hline \hline & & & \\
Age 20-64 & -1.99 & $-2.07^{* *}$ & -1.24 \\
$\mathrm{n}=23,702$ & $(1.33)$ & $(0.91)$ & $(1.22)$ \\
& & & \\
Age 20-55 & $-2.85^{* *}$ & $-2.30^{* * *}$ & $-2.35^{* *}$ \\
$\mathrm{n}=21,451$ & $(1.24)$ & $(0.83)$ & $(1.10)$ \\
& & & \\
Age 20-40 & $-2.56^{* *}$ & $-2.04^{* * *}$ & $-2.24^{* *}$ \\
$\mathrm{n}=12,097$ & $(1.14)$ & $(0.75)$ & $(0.98)$ \\
\hline
\end{tabular}

Note: ${ }^{*},{ }^{* *}$ and ${ }^{* * *}$ denote significance at the $10 \%, 5 \%$ and $1 \%$ level, respectively.

Source: German Socio-Economic Panel (GSOEP), own calculations. 
Table 5

Difference-in-differences quantile regression estimates

\begin{tabular}{|c|c|c|c|c|c|c|}
\hline Percentile & $\begin{array}{c}\text { Age } \\
20-64 \\
\end{array}$ & $\begin{array}{c}\text { Pre- } \\
\text { treatment } \\
\text { percentile } \\
\text { of } \\
\text { treatment } \\
\text { group } \\
\end{array}$ & $\begin{array}{c}\text { Age } \\
20-55 \\
\end{array}$ & $\begin{array}{c}\text { Pre- } \\
\text { treatment } \\
\text { percentile } \\
\text { of } \\
\text { treatment } \\
\text { group } \\
\end{array}$ & $\begin{array}{c}\text { Age } \\
20-40 \\
\end{array}$ & $\begin{array}{c}\text { Pre- } \\
\text { treatment } \\
\text { percentile } \\
\text { of } \\
\text { treatment } \\
\text { group } \\
\end{array}$ \\
\hline 40 & $\begin{array}{c}0.02 \\
(0.21)\end{array}$ & 0 & $\begin{array}{l}-0.07 \\
(0.14)\end{array}$ & 0 & $\begin{array}{l}-0.04 \\
(0.15)\end{array}$ & 0 \\
\hline 50 & $\begin{array}{l}-0.20 \\
(0.32)\end{array}$ & 2 & $\begin{array}{l}-0.39 \\
(0.29)\end{array}$ & 2 & $\begin{array}{c}0.01 \\
(0.59)\end{array}$ & 3 \\
\hline 60 & $\begin{array}{l}-0.28 \\
(0.45)\end{array}$ & 5 & $\begin{array}{l}-0.28 \\
(0.53)\end{array}$ & 5 & $\begin{array}{l}-0.71 \\
(0.72)\end{array}$ & 5 \\
\hline 70 & $\begin{array}{l}-0.79 \\
(0.56)\end{array}$ & 8 & $\begin{array}{l}-0.77^{*} \\
(0.45)\end{array}$ & 8 & $\begin{array}{c}-0.76^{* *} \\
(0.36)\end{array}$ & 8 \\
\hline 80 & $\begin{array}{l}-1.33 \\
(0.99)\end{array}$ & 14 & $\begin{array}{c}-1.32^{\star *} \\
(0.58)\end{array}$ & 14 & $\begin{array}{c}-1.18^{\star \star *} \\
(0.36)\end{array}$ & 14 \\
\hline 90 & $\begin{array}{c}-4.83^{* *} \\
(2.05)\end{array}$ & 23 & $\begin{array}{c}-4.85^{\star \star *} \\
(1.69)\end{array}$ & 21 & $\begin{array}{c}-3.94^{* *} \\
(1.53)\end{array}$ & 20 \\
\hline 95 & $\begin{array}{c}-9.30^{* * *} \\
(2.86)\end{array}$ & 40 & $\begin{array}{c}-7.66^{* * *} \\
(2.06)\end{array}$ & 35 & $\begin{array}{l}-4.01 \\
(2.52)\end{array}$ & 30 \\
\hline 98 & $\begin{array}{c}-10.49^{*} \\
(6.04)\end{array}$ & 65 & $\begin{array}{c}-15.84^{* *} \\
(6.30)\end{array}$ & 60 & $\begin{array}{l}-7.31 \\
(6.49)\end{array}$ & 50 \\
\hline OLS & $\begin{array}{l}-1.99 \\
(1.33)\end{array}$ & - & $\begin{array}{l}-2.85^{\star *} \\
(1.24)\end{array}$ & - & $\begin{array}{c}-2.56^{* *} \\
(1.14)\end{array}$ & - \\
\hline
\end{tabular}

$\begin{array}{llll}\mathrm{n} & 23,702 & 21,451 & 12,097\end{array}$

Note: ${ }^{*},{ }^{* *}$ and ${ }^{* * *}$ denote significance at the $10 \%, 5 \%$ and $1 \%$ level, respectively. Percentiles of 30 and lower are zero because more than $30 \%$ of the sample did not report a single day of absence. "pre-treatment percentile of treatment group" refers to the corresponding percentile of the treatment group in the pre-treatment period 1994 and 1995.

Source: German Socio-Economic Panel (GSOEP), own calculations. 
Table 6

Switch-on versus switch-off difference-in-differences estimates

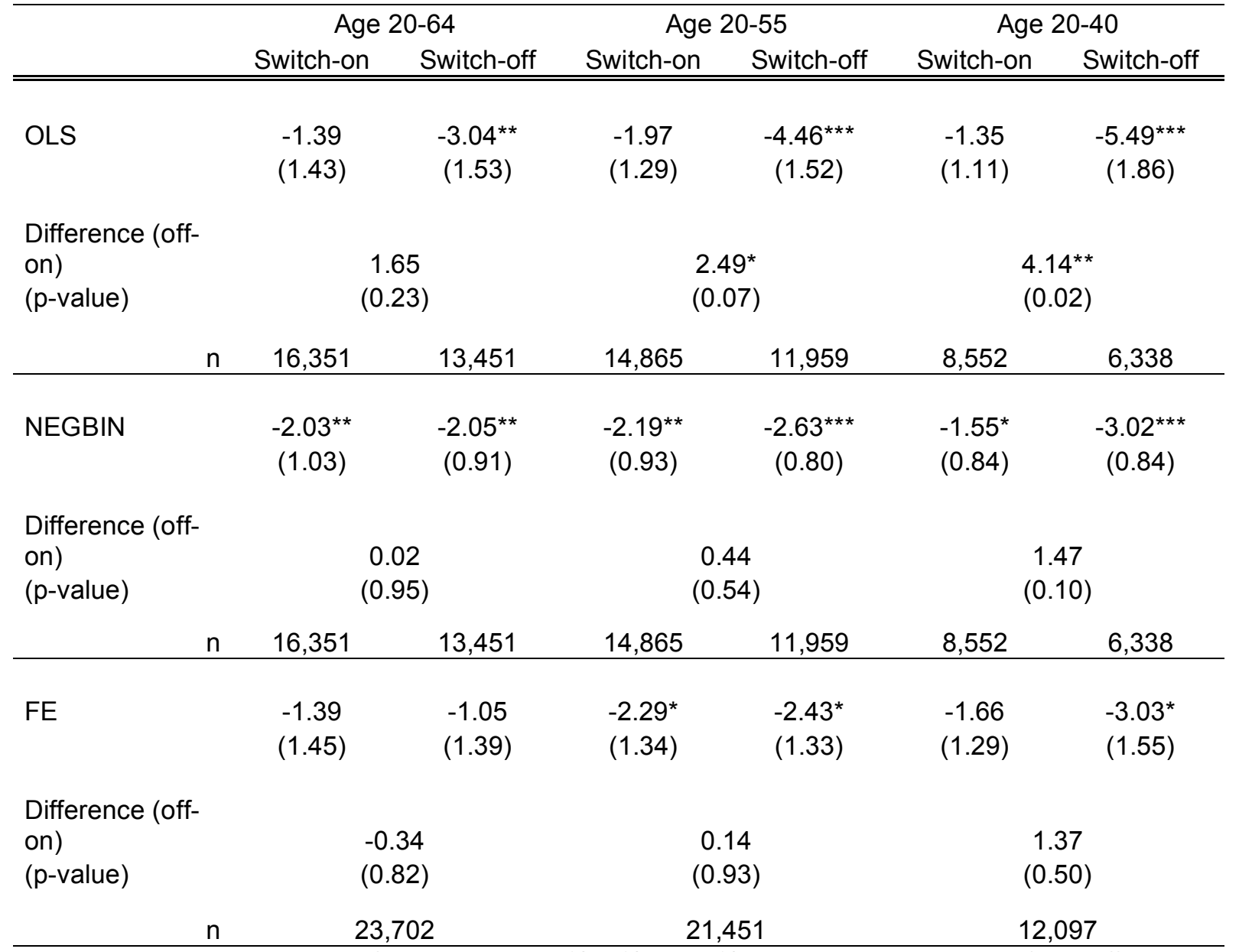

Note: ${ }^{*},{ }^{* *}$ and ${ }^{* * *}$ denote significance at the $10 \%, 5 \%$ and $1 \%$ level, respectively. The fixed-effects switch-on and switch-off estimates are obtained from a single fixed-effects regression equation.

Source: German Socio-Economic Panel (GSOEP), own calculations. 
Table 7

Switch-on versus switch-off quantile regression difference-in-differences estimates

Aged 20-64 Aged 20-55 Aged 20-40

\begin{tabular}{|c|c|c|c|c|c|c|}
\hline Percentile & Switch-on & Switch-off & Switch-on & Switch-off & Switch-on & Switch-off \\
\hline 40 & $\begin{array}{c}0.31 \\
(0.17)\end{array}$ & $\begin{array}{l}-0.05 \\
(0.22)\end{array}$ & $\begin{array}{l}-0.00 \\
(0.21)\end{array}$ & $\begin{array}{l}-0.28 \\
(0.22)\end{array}$ & $\begin{array}{c}0.27 \\
(0.23)\end{array}$ & $\begin{array}{c}-0.67^{* * *} \\
(0.01)\end{array}$ \\
\hline 50 & $\begin{array}{c}0.10 \\
(0.28)\end{array}$ & $\begin{array}{c}-0.65^{\star *} \\
(0.29)\end{array}$ & $\begin{array}{l}-0.20 \\
(0.55)\end{array}$ & $\begin{array}{c}-0.88^{* * *} \\
(0.28)\end{array}$ & $\begin{array}{l}0.41^{* *} \\
(0.20)\end{array}$ & $\begin{array}{c}-1.49^{* * *} \\
(0.37)\end{array}$ \\
\hline 60 & $\begin{array}{c}0.25 \\
(0.29)\end{array}$ & $\begin{array}{c}-0.93^{* *} \\
(0.39)\end{array}$ & $\begin{array}{c}0.08 \\
(0.56)\end{array}$ & $\begin{array}{c}-1.10^{* *} \\
(0.51)\end{array}$ & $\begin{array}{l}-0.32 \\
(0.61)\end{array}$ & $\begin{array}{c}-2.42^{* * *} \\
(0.21)\end{array}$ \\
\hline 70 & $\begin{array}{l}-0.49 \\
(0.45)\end{array}$ & $\begin{array}{c}-1.57^{* * *} \\
(0.38)\end{array}$ & $\begin{array}{l}-0.51 \\
(0.45)\end{array}$ & $\begin{array}{c}-1.68^{* * *} \\
(0.46)\end{array}$ & $\begin{array}{l}-0.18 \\
(0.37)\end{array}$ & $\begin{array}{c}-2.30^{* * *} \\
(0.49)\end{array}$ \\
\hline 80 & $\begin{array}{l}-0.94 \\
(0.84)\end{array}$ & $\begin{array}{c}-2.81^{* * *} \\
(0.72)\end{array}$ & $\begin{array}{l}-1.19 \\
(0.85)\end{array}$ & $\begin{array}{c}-2.19^{* * *} \\
(0.38)\end{array}$ & $\begin{array}{c}0.10 \\
(0.63)\end{array}$ & $\begin{array}{c}-3.44^{* * *} \\
(0.31)\end{array}$ \\
\hline 90 & $\begin{array}{l}-3.86^{* *} \\
(1.95)\end{array}$ & $\begin{array}{l}-4.33^{* *} \\
(1.75)\end{array}$ & $\begin{array}{l}-3.94^{* *} \\
(1.90)\end{array}$ & $\begin{array}{c}-5.31^{* * *} \\
(1.29)\end{array}$ & $\begin{array}{l}-2.05^{*} \\
(1.08)\end{array}$ & $\begin{array}{c}-7.71^{* * *} \\
(1.94)\end{array}$ \\
\hline 95 & $\begin{array}{c}-7.74^{* * *} \\
(2.65)\end{array}$ & $\begin{array}{c}-10.16^{* * *} \\
(2.56)\end{array}$ & $\begin{array}{c}-7.28^{* *} \\
(3.05)\end{array}$ & $\begin{array}{c}-10.75^{* * *} \\
(1.84)\end{array}$ & $\begin{array}{l}-4.37 \\
(3.34)\end{array}$ & $\begin{array}{c}-8.72^{* * *} \\
(2.85)\end{array}$ \\
\hline 98 & $\begin{array}{l}-10.68 \\
(8.66)\end{array}$ & $\begin{array}{l}-8.20 \\
(6.34)\end{array}$ & $\begin{array}{l}-9.62^{*} \\
(10.91)\end{array}$ & $\begin{array}{c}-13.05^{*} \\
(6.88)\end{array}$ & $\begin{array}{c}-2.80 \\
(10.44)\end{array}$ & $\begin{array}{c}-12.63^{* * *} \\
(4.77)\end{array}$ \\
\hline OLS & $\begin{array}{l}-1.39 \\
(1.43)\end{array}$ & $\begin{array}{c}-3.04^{* *} \\
(1.53)\end{array}$ & $\begin{array}{l}-1.97 \\
(1.29)\end{array}$ & $\begin{array}{c}-4.46^{* * *} \\
(1.52)\end{array}$ & $\begin{array}{l}-1.35 \\
(1.11)\end{array}$ & $\begin{array}{c}-5.49^{* * *} \\
(1.86)\end{array}$ \\
\hline
\end{tabular}

Note: ${ }^{*}{ }^{* *}$ and ${ }^{* * *}$ denote significance at the $10 \%, 5 \%$ and $1 \%$ level, respectively. Percentiles of 30 and lower are zero because more than $30 \%$ of the sample did not report a single day of absence.

Source: German Socio-Economic Panel (GSOEP), own calculations. 
Table 8

"Treatment effects" by calendar year (base year 1994) - including placebo estimates

OLS NEGBIN FE

\begin{tabular}{|c|c|c|c|}
\hline \multicolumn{4}{|l|}{ Age 20-64 } \\
\hline 1995 * no coll. agr. & $\begin{array}{c}-1.20 \\
(1.50)\end{array}$ & $\begin{array}{c}1.84 \\
(1.60)\end{array}$ & $\begin{array}{c}-0.91 \\
(1.33)\end{array}$ \\
\hline \multirow[t]{2}{*}{1997 * no coll. agr. } & -1.94 & -1.69 & -2.17 \\
\hline & $(1.81)$ & $(1.13)$ & $(1.53)$ \\
\hline \multirow[t]{2}{*}{1998 * no coll. agr. } & -2.45 & -0.63 & -1.52 \\
\hline & $(2.29)$ & $(1.80)$ & $(2.28)$ \\
\hline 1999 * no coll. agr. & $\begin{array}{c}0.90 \\
(1.68)\end{array}$ & $\begin{array}{c}0.77 \\
(1.39)\end{array}$ & $\begin{array}{c}-0.32 \\
(1.54)\end{array}$ \\
\hline 2000 * no coll. agr. & $\begin{array}{c}0.46 \\
(2.63)\end{array}$ & $\begin{array}{c}1.66 \\
(1.71) \\
\end{array}$ & $\begin{array}{c}-1.42 \\
(2.34)\end{array}$ \\
\hline \multicolumn{4}{|l|}{ Age 20-55 } \\
\hline $1995^{*}$ no coll. agr. & $\begin{array}{c}-0.31 \\
(1.30)\end{array}$ & $\begin{array}{c}2.48 \\
(1.58)\end{array}$ & $\begin{array}{c}-1.12 \\
(1.35)\end{array}$ \\
\hline \multirow[t]{2}{*}{1997 * no coll. agr. } & -1.95 & -1.27 & $-2.94^{*}$ \\
\hline & $(1.60)$ & $(1.06)$ & $(1.51)$ \\
\hline \multirow[t]{2}{*}{1998 * no coll. agr. } & -2.76 & -0.91 & $-2.90^{* *}$ \\
\hline & $(1.79)$ & $(1.58)$ & $(1.80)$ \\
\hline 1999 * no coll. agr. & $\begin{array}{c}1.54 \\
(1.48)\end{array}$ & $\begin{array}{c}1.28 \\
(1.36)\end{array}$ & $\begin{array}{c}-0.76 \\
(1.51)\end{array}$ \\
\hline 2000 * no coll. agr. & $\begin{array}{c}2.85 \\
(2.71) \\
\end{array}$ & $\begin{array}{c}3.45^{*} \\
(1.89)\end{array}$ & $\begin{array}{c}-0.21 \\
(2.51)\end{array}$ \\
\hline \multicolumn{4}{|l|}{ Age $20-40$} \\
\hline 1995 * no coll. agr. & $\begin{array}{c}-0.68 \\
(1.41)\end{array}$ & $\begin{array}{c}1.49 \\
(1.13)\end{array}$ & $\begin{array}{c}-2.11 \\
(1.69)\end{array}$ \\
\hline \multirow[t]{2}{*}{1997 * no coll. agr. } & -2.01 & -1.12 & $-3.15^{*}$ \\
\hline & $(1.53)$ & $(1.09)$ & $(1.61)$ \\
\hline \multirow[t]{2}{*}{1998 * no coll. agr. } & -1.58 & -0.7 & -2.60 \\
\hline & $(1.58)$ & $(1.33)$ & $(1.72)$ \\
\hline 1999 * no coll. agr. & $\begin{array}{c}1.20 \\
(1.57)\end{array}$ & $\begin{array}{c}1.62 \\
(1.62)\end{array}$ & $\begin{array}{c}-1.76 \\
(1.88)\end{array}$ \\
\hline 2000 * no coll. agr. & $\begin{array}{c}6.77 \\
(4.57)\end{array}$ & $\begin{array}{l}5.18^{* *} \\
(2.60)\end{array}$ & $\begin{array}{c}2.37 \\
(4.05)\end{array}$ \\
\hline
\end{tabular}

Note: ${ }^{*},{ }^{* *}$ and ${ }^{* * *}$ denote significance at the $10 \%, 5 \%$ and $1 \%$ level, respectively.

Source: German Socio-Economic Panel (GSOEP), own calculations. 
Table 9

Percentiles of other health-related outcomes

\begin{tabular}{cccc}
\hline & $\begin{array}{c}\text { Doctor visits } \\
\text { (last 3 months) }\end{array}$ & $\begin{array}{c}\text { Days in } \\
\text { hospital }\end{array}$ & $\begin{array}{c}\text { Number of } \\
\text { hospital stays }\end{array}$ \\
\hline \hline 30 & 0 & 0 & 0 \\
40 & 1 & 0 & 0 \\
50 & 1 & 0 & 0 \\
60 & 2 & 0 & 0 \\
70 & 2 & 0 & 0 \\
80 & 3 & 0 & 0 \\
90 & 6 & 0 & 0 \\
95 & 10 & 7 & 1 \\
96 & 10 & 10 & 1 \\
97 & 10 & 12 & 1 \\
98 & 12 & 15 & 1 \\
99 & 17 & 24 & 2 \\
100 & 90 & 220 & 20 \\
\hline Mean & 2.41 & 1.16 & 0.12 \\
\hline$n$ & 23,701 & 23,680 & 23,612 \\
\hline
\end{tabular}

Source: German Socio-Economic Panel (GSOEP), own calculations. 
Table 10

Effects on other health-related outcomes

\begin{tabular}{ccccc}
\hline & & & & Pre-reform \\
& OLS & NEGBIN & FE & mean \\
\hline \hline $\begin{array}{c}\text { Age 20-64 (n=23,702) } \\
\text { Doctor visits (last 3 months) }\end{array}$ & -0.26 & -0.21 & 0.03 & 2.2 \\
& $(0.18)$ & $(0.15)$ & $(0.15)$ & \\
Days in hospital & $-0.65^{* *}$ & $-0.41^{* * *}$ & $-0.62^{*}$ & 1.35 \\
& $(0.30)$ & $(0.11)$ & $(0.32)$ & \\
& & & & \\
Number of hospital stays & $-0.061^{* * *}$ & $-0.045^{* * *}$ & $-0.065^{* *}$ & 0.111 \\
& $(0.023)$ & $(0.012)$ & $(0.028)$ &
\end{tabular}

\begin{tabular}{|c|c|c|c|c|}
\hline \multicolumn{5}{|l|}{ Age 20-55 $\quad(n=21,451)$} \\
\hline \multirow[t]{2}{*}{ Doctor visits (last 3 months) } & -0.25 & -0.23 & -0.01 & 2.21 \\
\hline & $(0.19)$ & $(0.16)$ & $(0.16)$ & \\
\hline \multirow[t]{2}{*}{ Days in hospital } & $-0.67^{* *}$ & $-0.37^{* * *}$ & $-0.73^{* *}$ & 1.12 \\
\hline & $(0.28)$ & $(0.10)$ & $(0.34)$ & \\
\hline \multirow{2}{*}{ Number of hospital stays } & $-0.068^{* * *}$ & $-0.046^{\star * *}$ & $-0.065^{* *}$ & 0.108 \\
\hline & $(0.024)$ & $(0.012)$ & $(0.031)$ & \\
\hline \multicolumn{5}{|l|}{ Age 20-40 $\quad(n=12,097)$} \\
\hline \multirow[t]{2}{*}{ Doctor visits (last 3 months) } & $-0.42^{*}$ & $-0.34^{* *}$ & -0.26 & 1.91 \\
\hline & $(0.22)$ & $(0.17)$ & $(0.19)$ & \\
\hline \multirow[t]{2}{*}{ Days in hospital } & $-0.53^{* *}$ & $-0.25^{*}$ & $-0.68^{* *}$ & 0.65 \\
\hline & $(0.23)$ & $(0.15)$ & $(0.29)$ & \\
\hline \multirow[t]{2}{*}{ Number of hospital stays } & $-0.079 * * *$ & $-0.050^{* * *}$ & $-0.085^{\star}$ & 0.084 \\
\hline & $(0.031)$ & $(0.012)$ & $(0.047)$ & \\
\hline
\end{tabular}

Note: ${ }^{*},{ }^{* *}$ and ${ }^{* * *}$ denote significance at the $10 \%, 5 \%$ and $1 \%$ level, respectively. The "pre-reform mean" refers to the treatment group in the pre-treatment period 1994 and 1995.

Source: German Socio-Economic Panel (GSOEP), own calculations. 
Table 11

Effects on subjective health indicators (full sample)

\begin{tabular}{|c|c|c|c|c|c|}
\hline OLS & $\begin{array}{c}\text { OLS - } \\
\text { switch on }\end{array}$ & $\begin{array}{c}\text { OLS - } \\
\text { switch off }\end{array}$ & $\mathrm{FE}$ & $\begin{array}{c}\text { FE - } \\
\text { switch on }\end{array}$ & $\begin{array}{c}\text { FE - } \\
\text { switch off }\end{array}$ \\
\hline
\end{tabular}

Health at present

\begin{tabular}{|c|c|c|c|c|c|c|c|}
\hline Age $20-64$ & $\begin{array}{l}-0.008 \\
(0.013)\end{array}$ & $\begin{array}{l}-0.000 \\
(0.014)\end{array}$ & $\begin{array}{l}-0.022 \\
(0.014)\end{array}$ & $\begin{array}{l}-0.007 \\
(0.011)\end{array}$ & $\begin{array}{c}0.003 \\
(0.012)\end{array}$ & $\begin{array}{l}-0.021^{*} \\
(0.012)\end{array}$ & 0.63 \\
\hline$n$ & 23,702 & 16,351 & 13,451 & 23,702 & \multicolumn{2}{|c|}{23,702} & \\
\hline Age $20-55$ & $\begin{array}{l}-0.011 \\
(0.014)\end{array}$ & $\begin{array}{l}-0.005 \\
(0.014)\end{array}$ & $\begin{array}{c}-0.024 \\
(0.015)\end{array}$ & $\begin{array}{l}-0.006 \\
(0.011)\end{array}$ & $\begin{array}{c}0.005 \\
(0.013)\end{array}$ & $\begin{array}{l}-0.020 \\
(0.013)\end{array}$ & 0.63 \\
\hline$n$ & 21,451 & 14,865 & 11,959 & 21,451 & \multicolumn{2}{|c|}{21,451} & \\
\hline Age $20-40$ & $\begin{array}{c}0.003 \\
(0.020)\end{array}$ & $\begin{array}{c}0.018 \\
(0.021)\end{array}$ & $\begin{array}{l}-0.034 \\
(0.022)\end{array}$ & $\begin{array}{l}-0.002 \\
(0.018)\end{array}$ & $\begin{array}{c}0.020 \\
(0.020)\end{array}$ & $\begin{array}{l}-0.031^{*} \\
(0.018)\end{array}$ & 0.66 \\
\hline$n$ & 12,097 & 8,552 & 6,338 & 12,097 & \multicolumn{2}{|c|}{12,097} & \\
\hline
\end{tabular}

Satisfaction with health

\begin{tabular}{|c|c|c|c|c|c|c|c|}
\hline Age $20-64$ & $\begin{array}{l}-0.021 * \\
(0.011)\end{array}$ & $\begin{array}{l}-0.019 \\
(0.012)\end{array}$ & $\begin{array}{c}-0.025^{* *} \\
(0.012)\end{array}$ & $\begin{array}{l}-0.011 \\
(0.008)\end{array}$ & $\begin{array}{l}-0.008 \\
(0.009)\end{array}$ & $\begin{array}{l}-0.015 \\
(0.010)\end{array}$ & 0.69 \\
\hline $\mathrm{n}$ & 23,702 & 16,351 & 13,451 & 23,702 & \multicolumn{2}{|c|}{23,702} & \\
\hline Age 20-55 & $\begin{array}{l}-0.019 \\
(0.013)\end{array}$ & $\begin{array}{l}-0.018 \\
(0.014)\end{array}$ & $\begin{array}{l}-0.023^{*} \\
(0.014)\end{array}$ & $\begin{array}{l}-0.005 \\
(0.008)\end{array}$ & $\begin{array}{l}-0.002 \\
(0.009)\end{array}$ & $\begin{array}{l}-0.010 \\
(0.010)\end{array}$ & 0.70 \\
\hline $\mathrm{n}$ & 21,451 & 14,865 & 11,959 & 21,451 & \multicolumn{2}{|c|}{21,451} & \\
\hline Age $20-40$ & $\begin{array}{c}-0.009 \\
(0.018)\end{array}$ & $\begin{array}{c}-0.005 \\
(0.020)\end{array}$ & $\begin{array}{c}-0.023 \\
(0.018)\end{array}$ & $\begin{array}{c}-0.009 \\
(0.011)\end{array}$ & $\begin{array}{c}-0.006 \\
(0.014)\end{array}$ & $\begin{array}{c}-0.012 \\
(0.013)\end{array}$ & 0.71 \\
\hline $\mathrm{n}$ & 12,097 & 8,552 & 6,338 & 12,097 & \multicolumn{2}{|c|}{12,097} & \\
\hline \multicolumn{8}{|c|}{$\begin{array}{l}\text { Note: }{ }^{*},{ }^{* *} \text { and }{ }^{* * *} \text { denote significance at the } 10 \%, 5 \% \text { and } 1 \% \text { level, respectively. Both indicators } \\
\text { range between } 0 \text { and } 1 \text { with } 1 \text { indicating very good health. Health at Present is coded in } 5 \text {, } \\
\text { Satisfaction with Health in } 11 \text { different values. The fixed-effects switch-on and switch-off estimates } \\
\text { are obtained from a single fixed-effects regression equation. The "pre-reform mean“ refers to the } \\
\text { treatment group in the pre-treatment period } 1994 \text { and } 1995 . \\
\text { Source: German Socio-Economic Panel (GSOEP), own calculations. }\end{array}$} \\
\hline
\end{tabular}


Table 12

Effects on subjective health indicators in the following year (full sample)

\begin{tabular}{|c|c|c|c|c|c|}
\hline OLS & $\begin{array}{c}\text { OLS - } \\
\text { switch on }\end{array}$ & $\begin{array}{l}\text { OLS - } \\
\text { switch off }\end{array}$ & FE & $\begin{array}{c}\text { FE - } \\
\text { switch on }\end{array}$ & $\begin{array}{c}\text { FE - } \\
\text { switch off }\end{array}$ \\
\hline
\end{tabular}

Health at present (next year)

\begin{tabular}{|c|c|c|c|c|c|c|c|}
\hline Age 20-64 & $\begin{array}{c}0.008 \\
(0.012)\end{array}$ & $\begin{array}{c}0.004 \\
(0.013)\end{array}$ & $\begin{array}{c}0.017 \\
(0.014)\end{array}$ & $\begin{array}{c}0.010 \\
(0.008)\end{array}$ & $\begin{array}{c}0.008 \\
(0.009)\end{array}$ & $\begin{array}{c}0.013 \\
(0.010)\end{array}$ & 0.63 \\
\hline $\mathrm{n}$ & 23,674 & 16,328 & 13,438 & 23,674 & \multicolumn{2}{|c|}{23,674} & \\
\hline Age 20-55 & $\begin{array}{c}0.005 \\
(0.012)\end{array}$ & $\begin{array}{c}-0.002 \\
(0.014)\end{array}$ & $\begin{array}{c}0.018 \\
(0.015)\end{array}$ & $\begin{array}{c}0.011 \\
(0.009)\end{array}$ & $\begin{array}{c}0.010 \\
(0.009)\end{array}$ & $\begin{array}{c}0.014 \\
(0.011)\end{array}$ & 0.64 \\
\hline $\mathrm{n}$ & 21,426 & 14,844 & 11,948 & 21,426 & \multicolumn{2}{|c|}{21,426} & \\
\hline Age $20-40$ & $\begin{array}{c}0.013 \\
(0.017)\end{array}$ & $\begin{array}{c}0.011 \\
(0.018)\end{array}$ & $\begin{array}{c}0.019 \\
(0.023)\end{array}$ & $\begin{array}{c}0.015 \\
(0.012)\end{array}$ & $\begin{array}{c}0.019 \\
(0.014)\end{array}$ & $\begin{array}{c}0.010 \\
(0.017)\end{array}$ & 0.67 \\
\hline $\mathrm{n}$ & 12,085 & 8,543 & 6,334 & 12,085 & & & \\
\hline
\end{tabular}

Satisfaction with health (next year)

\begin{tabular}{|c|c|c|c|c|c|c|c|}
\hline Age $20-64$ & $\begin{array}{c}-0.005 \\
(0.011)\end{array}$ & $\begin{array}{l}-0.010 \\
(0.012)\end{array}$ & $\begin{array}{c}0.004 \\
(0.013)\end{array}$ & $\begin{array}{c}0.001 \\
(0.008)\end{array}$ & $\begin{array}{c}0.001 \\
(0.009)\end{array}$ & $\begin{array}{c}0.000 \\
(0.009)\end{array}$ & 0.69 \\
\hline $\mathrm{n}$ & 23,674 & 16,328 & 13,438 & 23,674 & \multicolumn{2}{|c|}{23,674} & \\
\hline Age 20-55 & $\begin{array}{l}-0.007 \\
(0.012)\end{array}$ & $\begin{array}{c}-0.014 \\
(0.013)\end{array}$ & $\begin{array}{c}0.005 \\
(0.014)\end{array}$ & $\begin{array}{c}0.000 \\
(0.008)\end{array}$ & $\begin{array}{c}-0.001 \\
(0.010)\end{array}$ & $\begin{array}{c}0.002 \\
(0.009)\end{array}$ & 0.69 \\
\hline $\mathrm{n}$ & 21,426 & 14,844 & 11,948 & 21,426 & \multicolumn{2}{|c|}{21,426} & \\
\hline Age $20-40$ & $\begin{array}{l}-0.010 \\
(0.017)\end{array}$ & $\begin{array}{c}-0.014 \\
(0.018)\end{array}$ & $\begin{array}{c}-0.004 \\
(0.020)\end{array}$ & $\begin{array}{l}-0.012 \\
(0.012)\end{array}$ & $\begin{array}{c}-0.012 \\
(0.015)\end{array}$ & $\begin{array}{c}-0.012 \\
(0.014)\end{array}$ & 0.72 \\
\hline $\mathrm{n}$ & 12,085 & 8,543 & 6,334 & 12,085 & \multicolumn{2}{|c|}{12,085} & \\
\hline \multicolumn{8}{|c|}{$\begin{array}{l}\text { Note: }{ }^{*},{ }^{* *} \text { and }{ }^{* * *} \text { denote significance at the } 10 \%, 5 \% \text { and } 1 \% \text { level, respectively. Both indicators } \\
\text { range between } 0 \text { and } 1 \text { with } 1 \text { indicating very good health. Health at Present (next year) is coded in } 5 \text {, } \\
\text { Satisfaction with Health (next year) in } 11 \text { different values. The fixed-effects switch-on and switch-off } \\
\text { estimates are obtained from a single fixed-effects regression equation. The "pre-reform mean" refers } \\
\text { to the treatment group in the pre-treatment period } 1994 \text { and } 1995 . \\
\text { Source: German Socio-Economic Panel (GSOEP), own calculations. }\end{array}$} \\
\hline
\end{tabular}


Table 13

Effects on subjective health indicators for the sample of people with positive number of doctor visits

\begin{tabular}{|c|c|c|c|c|c|c|}
\hline OLS & $\begin{array}{c}\text { OLS - } \\
\text { switch on }\end{array}$ & $\begin{array}{l}\text { OLS - } \\
\text { switch off }\end{array}$ & FE & $\begin{array}{c}\text { FE - } \\
\text { switch on }\end{array}$ & $\begin{array}{c}\text { FE - } \\
\text { switch off }\end{array}$ & $\begin{array}{c}\text { Pre-reform } \\
\text { mean }\end{array}$ \\
\hline
\end{tabular}

\section{Health at present}

\begin{tabular}{|c|c|c|c|c|c|c|c|}
\hline Age $20-64$ & $\begin{array}{c}-0.012 \\
(0.018)\end{array}$ & $\begin{array}{c}-0.009 \\
(0.019)\end{array}$ & $\begin{array}{l}-0.020 \\
(0.020)\end{array}$ & $\begin{array}{l}-0.005 \\
(0.017)\end{array}$ & $\begin{array}{c}0.005 \\
(0.019)\end{array}$ & $\begin{array}{c}-0.017 \\
(0.018)\end{array}$ & 0.61 \\
\hline$n$ & 15,664 & 10,790 & 8,906 & 15,664 & \multicolumn{2}{|c|}{15,664} & \\
\hline Age $20-55$ & $\begin{array}{c}-0.015 \\
(0.020)\end{array}$ & $\begin{array}{c}-0.012 \\
(0.021)\end{array}$ & $\begin{array}{l}-0.024 \\
(0.022)\end{array}$ & $\begin{array}{l}-0.010 \\
(0.018)\end{array}$ & $\begin{array}{l}-0.001 \\
(0.020)\end{array}$ & $\begin{array}{l}-0.021 \\
(0.020)\end{array}$ & 0.61 \\
\hline$n$ & 13,903 & 9,631 & 7,724 & 13,903 & \multicolumn{2}{|c|}{13,903} & \\
\hline Age $20-40$ & $\begin{array}{c}-0.015 \\
(0.032)\end{array}$ & $\begin{array}{c}0.002 \\
(0.032)\end{array}$ & $\begin{array}{l}-0.053 \\
(0.032)\end{array}$ & $\begin{array}{l}-0.030 \\
(0.033)\end{array}$ & $\begin{array}{l}-0.010 \\
(0.036)\end{array}$ & $\begin{array}{l}-0.059^{*} \\
(0.032)\end{array}$ & 0.64 \\
\hline $\mathrm{n}$ & 7,637 & 5,411 & 3,977 & 7,637 & & & \\
\hline
\end{tabular}

Satisfaction with health

\begin{tabular}{|c|c|c|c|c|c|c|c|}
\hline Age $20-64$ & $\begin{array}{l}-0.028^{*} \\
(0.016)\end{array}$ & $\begin{array}{l}-0.029 * \\
(0.017)\end{array}$ & $\begin{array}{l}-0.028 \\
(0.017)\end{array}$ & $\begin{array}{l}-0.009 \\
(0.011)\end{array}$ & $\begin{array}{l}-0.007 \\
(0.014)\end{array}$ & $\begin{array}{l}-0.011 \\
(0.013)\end{array}$ & 0.67 \\
\hline $\mathrm{n}$ & 15,664 & 10,790 & 8,906 & 15,664 & \multicolumn{2}{|c|}{15,664} & \\
\hline Age 20-55 & $\begin{array}{l}-0.025 \\
(0.018)\end{array}$ & $\begin{array}{l}-0.027 \\
(0.019)\end{array}$ & $\begin{array}{l}-0.023 \\
(0.019)\end{array}$ & $\begin{array}{c}0.000 \\
(0.012)\end{array}$ & $\begin{array}{c}0.003 \\
(0.015)\end{array}$ & $\begin{array}{l}-0.003 \\
(0.014)\end{array}$ & 0.67 \\
\hline $\mathrm{n}$ & 13,903 & 9,631 & 7,724 & 13,903 & \multicolumn{2}{|c|}{13,903} & \\
\hline Age $20-40$ & $\begin{array}{l}-0.014 \\
(0.027)\end{array}$ & $\begin{array}{l}-0.011 \\
(0.030)\end{array}$ & $\begin{array}{l}-0.019 \\
(0.025)\end{array}$ & $\begin{array}{l}-0.018 \\
(0.018)\end{array}$ & $\begin{array}{l}-0.015 \\
(0.024)\end{array}$ & $\begin{array}{l}-0.023 \\
(0.016)\end{array}$ & 0.69 \\
\hline $\mathrm{n}$ & 7,637 & 5,411 & 3,977 & 7,637 & \multicolumn{2}{|c|}{7,637} & \\
\hline $\begin{array}{l}\text { Note: }{ }^{*},{ }^{* *} \text { a } \\
\text { range betwe } \\
\text { Satisfaction } \\
\text { are obtainec } \\
\text { treatment gr } \\
\text { Source: Ger }\end{array}$ & $\begin{array}{l}\text { ind } 1 \mathrm{w} \\
\text { ealth it } \\
\text { a singl } \\
\text { the pr } \\
\text { ocio-E }\end{array}$ & $\begin{array}{l}\text { ndicating } \\
\text { ifferent } \\
\text { d-effects } \\
\text { tment pe } \\
\text { nic Pane }\end{array}$ & $\begin{array}{l}\text { ry good h } \\
\text { es. The fi> } \\
\text { ression e } \\
1994 \text { an } \\
\text { SOEP), o }\end{array}$ & $\begin{array}{l}1 \% \text { lev } \\
\text { Health } \\
\text { ffects s } \\
\text { n. The } \\
5 . \\
\text { alculatio }\end{array}$ & $\begin{array}{l}\text { spective } \\
\text { esent is } \\
\text { on and } \\
\text { eform m }\end{array}$ & $\begin{array}{l}\text { th indica } \\
d \text { in } 5, \\
\text {-off estir } \\
\text { refers to }\end{array}$ & \\
\hline
\end{tabular}


Table 14

Effects on subjective health indicators in the following year for the sample of people with positive number of doctor visits in the current year

\begin{tabular}{|c|c|c|c|c|c|c|}
\hline OLS & $\begin{array}{c}\text { OLS - } \\
\text { switch on }\end{array}$ & $\begin{array}{c}\text { OLS - } \\
\text { switch off }\end{array}$ & FE & $\begin{array}{c}\text { FE - } \\
\text { switch on }\end{array}$ & $\begin{array}{c}\text { FE - } \\
\text { switch off }\end{array}$ & $\begin{array}{l}\text { Pre-reform } \\
\text { mean }\end{array}$ \\
\hline
\end{tabular}

\section{Health at present (next year)}

\begin{tabular}{|c|c|c|c|c|c|c|c|}
\hline Age $20-64$ & $\begin{array}{c}0.006 \\
(0.014)\end{array}$ & $\begin{array}{l}-0.000 \\
(0.015)\end{array}$ & $\begin{array}{c}0.017 \\
(0.018)\end{array}$ & $\begin{array}{c}0.013 \\
(0.012)\end{array}$ & $\begin{array}{c}0.014 \\
(0.013)\end{array}$ & $\begin{array}{c}0.013 \\
(0.014)\end{array}$ & 0.60 \\
\hline $\mathrm{n}$ & 15,652 & 10,780 & 8,898 & 15,652 & \multicolumn{2}{|c|}{15,652} & \\
\hline Age $20-55$ & $\begin{array}{c}0.006 \\
(0.016)\end{array}$ & $\begin{array}{l}-0.003 \\
(0.017)\end{array}$ & $\begin{array}{c}0.022 \\
(0.019)\end{array}$ & $\begin{array}{c}0.014 \\
(0.013)\end{array}$ & $\begin{array}{c}0.013 \\
(0.014)\end{array}$ & $\begin{array}{c}0.015 \\
(0.016)\end{array}$ & 0.60 \\
\hline $\mathrm{n}$ & 13,893 & 9,623 & 7,717 & 13,893 & \multicolumn{2}{|c|}{13,893} & \\
\hline Age $20-40$ & $\begin{array}{c}0.016 \\
(0.021)\end{array}$ & $\begin{array}{c}0.014 \\
(0.021)\end{array}$ & $\begin{array}{c}0.025 \\
(0.030)\end{array}$ & $\begin{array}{l}0.033^{*} \\
(0.018)\end{array}$ & $\begin{array}{l}0.045^{* *} \\
(0.018)\end{array}$ & $\begin{array}{c}0.015 \\
(0.024)\end{array}$ & 0.64 \\
\hline $\mathrm{n}$ & 7,633 & 5,409 & 3,974 & 7,633 & & & \\
\hline
\end{tabular}

Satisfaction with health (next year)

\begin{tabular}{|c|c|c|c|c|c|c|c|}
\hline Age $20-64$ & $\begin{array}{c}-0.012 \\
(0.014)\end{array}$ & $\begin{array}{c}-0.017 \\
(0.015)\end{array}$ & $\begin{array}{l}-0.004 \\
(0.017)\end{array}$ & $\begin{array}{c}0.003 \\
(0.010)\end{array}$ & $\begin{array}{c}0.012 \\
(0.012)\end{array}$ & $\begin{array}{l}-0.009 \\
(0.012)\end{array}$ & 0.66 \\
\hline $\mathrm{n}$ & 15,652 & 10,780 & 8,898 & 15,652 & \multicolumn{2}{|c|}{15,652} & \\
\hline Age $20-55$ & $\begin{array}{c}-0.014 \\
(0.015)\end{array}$ & $\begin{array}{l}-0.021 \\
(0.017)\end{array}$ & $\begin{array}{c}-0.003 \\
(0.019)\end{array}$ & $\begin{array}{c}0.005 \\
(0.011)\end{array}$ & $\begin{array}{c}0.013 \\
(0.013)\end{array}$ & $\begin{array}{l}-0.006 \\
(0.013)\end{array}$ & 0.66 \\
\hline $\mathrm{n}$ & 13,893 & 9,623 & 7,717 & 13,893 & \multicolumn{2}{|c|}{13,893} & \\
\hline Age $20-40$ & $\begin{array}{l}-0.009 \\
(0.022)\end{array}$ & $\begin{array}{l}-0.009 \\
(0.024)\end{array}$ & $\begin{array}{l}-0.007 \\
(0.028)\end{array}$ & $\begin{array}{c}0.012 \\
(0.016)\end{array}$ & $\begin{array}{c}0.029 \\
(0.018)\end{array}$ & $\begin{array}{l}-0.013 \\
(0.019)\end{array}$ & 0.68 \\
\hline $\mathrm{n}$ & 7,633 & 5,409 & 3,974 & 7,633 & \multicolumn{2}{|c|}{7,633} & \\
\hline $\begin{array}{l}\text { Note: }{ }^{*},{ }^{* *} \text { a } \\
\text { range betwe } \\
\text { Satisfaction } \\
\text { estimates a } \\
\text { to the treatn } \\
\text { Source: Ger }\end{array}$ & $\begin{array}{l}\text { denote } \\
\text { and } 1 \mathrm{w} \\
\text { Health (r } \\
\text { ained frc } \\
\text { roup in } \\
\text { Socio-E }\end{array}$ & $\begin{array}{l}\text { icance a } \\
\text { ndicating } \\
\text { ear) in } 1 \\
\text { single fix } \\
\text { e-treatm } \\
\text { nic Pane }\end{array}$ & $\begin{array}{l}10 \%, 5 \% \\
y \text { good he } \\
\text { erent val } \\
\text { ffects reg } \\
\text { eriod } 19 \\
\text { SOEP), o }\end{array}$ & $\begin{array}{l}1 \% \text { le } \\
\text { Health } \\
\text { The fix } \\
\text { ion equ } \\
\text { nd } 1995 \\
\text { alculati }\end{array}$ & $\begin{array}{l}\text { pectiv } \\
\text { sent } \\
\text { ets sy } \\
\text { The " } p\end{array}$ & $\begin{array}{l}\text { th indi } \\
\text { ar) is } \\
\text { and } s \\
\mathrm{rm} \text { me }\end{array}$ & $\begin{array}{l}\text { in } 5 \text {, } \\
\text { off } \\
\text { fers }\end{array}$ \\
\hline
\end{tabular}


Table 15

Effects on subjective health indicators for the sample of people with positive number of days in hospital

\begin{tabular}{|c|c|c|c|c|c|c|}
\hline OLS & $\begin{array}{c}\text { OLS - } \\
\text { switch on }\end{array}$ & $\begin{array}{c}\text { OLS - } \\
\text { switch off }\end{array}$ & FE & $\begin{array}{c}\text { FE - } \\
\text { switch on }\end{array}$ & $\begin{array}{c}\text { FE - } \\
\text { switch off }\end{array}$ & $\begin{array}{c}\text { Pre-reform } \\
\text { mean }\end{array}$ \\
\hline
\end{tabular}

\section{Health at present}

\begin{tabular}{|c|c|c|c|c|c|c|c|}
\hline Age 20-64 & $\begin{array}{l}-0.036 \\
(0.043)\end{array}$ & $\begin{array}{c}-0.044 \\
(0.047)\end{array}$ & $\begin{array}{l}-0.025 \\
(0.045)\end{array}$ & $\begin{array}{c}0.045 \\
(0.061)\end{array}$ & $\begin{array}{c}0.113^{*} \\
(0.067)\end{array}$ & $\begin{array}{c}0.016 \\
(0.064)\end{array}$ & 0.56 \\
\hline $\mathrm{n}$ & 2,183 & 1,533 & 1,242 & 2,183 & \multicolumn{2}{|c|}{2,183} & \\
\hline Age 20-55 & $\begin{array}{l}-0.040 \\
(0.055)\end{array}$ & $\begin{array}{c}-0.066 \\
(0.057)\end{array}$ & $\begin{array}{l}-0.001 \\
(0.056)\end{array}$ & $\begin{array}{c}0.062 \\
(0.083)\end{array}$ & $\begin{array}{c}0.070 \\
(0.086)\end{array}$ & $\begin{array}{c}0.057 \\
(0.093)\end{array}$ & 0.58 \\
\hline $\mathrm{n}$ & 1,890 & 1,334 & 1,041 & 1,890 & & & \\
\hline Age $20-40$ & $\begin{array}{c}0.034 \\
(0.058)\end{array}$ & $\begin{array}{c}0.009 \\
(0.056)\end{array}$ & $\begin{array}{c}0.073 \\
(0.072)\end{array}$ & - & - & - & 0.62 \\
\hline $\mathrm{n}$ & 1,034 & 726 & 555 & & & & \\
\hline
\end{tabular}

Satisfaction with health

\begin{tabular}{|c|c|c|c|c|c|c|c|}
\hline Age 20-64 & $\begin{array}{l}-0.055 \\
(0.049)\end{array}$ & $\begin{array}{c}-0.071 \\
(0.051)\end{array}$ & $\begin{array}{l}-0.026 \\
(0.049)\end{array}$ & $\begin{array}{c}0.041 \\
(0.045)\end{array}$ & $\begin{array}{c}0.042 \\
(0.057)\end{array}$ & $\begin{array}{c}0.040 \\
(0.049)\end{array}$ & 0.63 \\
\hline $\mathrm{n}$ & 2,183 & 1,533 & 1,242 & 2,183 & \multicolumn{2}{|c|}{2,183} & \\
\hline Age 20-55 & $\begin{array}{c}-0.047 \\
(0.064)\end{array}$ & $\begin{array}{c}-0.073 \\
(0.064)\end{array}$ & $\begin{array}{l}-0.000 \\
(0.062)\end{array}$ & $\begin{array}{c}0.031 \\
(0.058)\end{array}$ & $\begin{array}{c}0.024 \\
(0.070)\end{array}$ & $\begin{array}{c}0.036 \\
(0.031)\end{array}$ & 0.63 \\
\hline $\mathrm{n}$ & 1,890 & 1,334 & 1,041 & 1,890 & \multicolumn{2}{|c|}{1,890} & \\
\hline Age $20-40$ & $\begin{array}{l}0.106^{* *} \\
(0.042)\end{array}$ & $\begin{array}{c}0.066 \\
(0.050)\end{array}$ & $\begin{array}{c}0.163^{* * *} \\
(0.053)\end{array}$ & - & - & - & 0.66 \\
\hline $\mathrm{n}$ & 1,034 & 726 & 555 & & & & \\
\hline \multicolumn{8}{|c|}{$\begin{array}{l}\text { Note: }{ }^{*},{ }^{* *} \text { and }{ }^{* * *} \text { denote significance at the } 10 \%, 5 \% \text { and } 1 \% \text { level, respectively. Both indicators } \\
\text { range between } 0 \text { and } 1 \text { with } 1 \text { indicating very good health. Health at Present is coded in } 5 \text {, } \\
\text { Satisfaction with Health in } 11 \text { different values. The OLS results for the age group } 20-40 \text { are only } \\
\text { based on } 29 \text { persons who are in the treatment group in the treatment period. Hence, statistical } \\
\text { inference on these coefficients may be invalid, so that we do not take the statistical significance of the } \\
\text { positive coefficients for "Satisfaction with Health" seriously. We do not report fixed-effects estimates } \\
\text { for this age group because we only have } 10 \text { persons with a within variation in the treatment indicator. } \\
\text { For the age groups } 20-64 \text { and } 20-55 \text { the number of persons with a within-variation in the treatment } \\
\text { indicator is } 26 \text { (13 switch on and } 17 \text { switch off) and } 21 \text { (11 switch on and } 13 \text { switch off), respectively. } \\
\text { Hence, these estimates have to be taken with a grain of salt. The fixed-effects switch-on and switch- } \\
\text { off estimates are obtained from a single fixed-effects regression equation. The "pre-reform mean" } \\
\text { refers to the treatment group in the pre-treatment period } 1994 \text { and } 1995 \text {. } \\
\text { Source: German Socio-Economic Panel (GSOEP), own calculations. }\end{array}$} \\
\hline
\end{tabular}


Table 16

Effects on subjective health indicators in the following year for the sample of people with positive number of days in hospital in the current year

\begin{tabular}{ccccccc} 
OLS & $\begin{array}{c}\text { OLS - } \\
\text { switch on }\end{array}$ & $\begin{array}{c}\text { OLS - } \\
\text { switch off }\end{array}$ & FE & $\begin{array}{c}\text { FE - } \\
\text { switch on }\end{array}$ & $\begin{array}{c}\text { FE - } \\
\text { switch off }\end{array}$ & $\begin{array}{c}\text { Pre-reform } \\
\text { mean }\end{array}$ \\
\hline
\end{tabular}

Health at present (next year)

\begin{tabular}{|c|c|c|c|c|c|c|c|}
\hline Age $20-64$ & $\begin{array}{c}0.002 \\
(0.045)\end{array}$ & $\begin{array}{c}0.010 \\
(0.048)\end{array}$ & $\begin{array}{c}-0.002 \\
(0.052)\end{array}$ & $\begin{array}{c}0.006 \\
(0.056)\end{array}$ & $\begin{array}{l}-0.066 \\
(0.068)\end{array}$ & $\begin{array}{c}0.038 \\
(0.056)\end{array}$ & 0.52 \\
\hline $\mathrm{n}$ & 2,181 & 1,532 & 1,241 & 2,181 & \multicolumn{2}{|c|}{2,181} & \\
\hline Age $20-55$ & $\begin{array}{l}-0.008 \\
(0.053)\end{array}$ & $\begin{array}{l}-0.015 \\
(0.054)\end{array}$ & $\begin{array}{c}0.020 \\
(0.059)\end{array}$ & $\begin{array}{l}-0.021 \\
(0.054)\end{array}$ & $\begin{array}{l}-0.079 \\
(0.072)\end{array}$ & $\begin{array}{c}0.015 \\
(0.054)\end{array}$ & 0.54 \\
\hline $\mathrm{n}$ & 1,888 & 1,333 & 1,040 & 1,890 & \multicolumn{2}{|c|}{1,890} & \\
\hline Age $20-40$ & $\begin{array}{c}0.053 \\
(0.064)\end{array}$ & $\begin{array}{c}0.048 \\
(0.060)\end{array}$ & $\begin{array}{c}0.109 \\
(0.071)\end{array}$ & - & - & - & 0.60 \\
\hline $\mathrm{n}$ & 1,033 & 725 & 555 & & & & \\
\hline
\end{tabular}

Satisfaction with health (next year)

\begin{tabular}{|c|c|c|c|c|c|c|c|}
\hline Age $20-64$ & $\begin{array}{l}-0.005 \\
(0.041)\end{array}$ & $\begin{array}{c}-0.002 \\
(0.044)\end{array}$ & $\begin{array}{c}0.004 \\
(0.050)\end{array}$ & $\begin{array}{l}-0.059 \\
(0.053)\end{array}$ & $\begin{array}{c}-0.062 \\
(0.065)\end{array}$ & $\begin{array}{l}-0.057 \\
(0.054)\end{array}$ & 0.59 \\
\hline $\mathrm{n}$ & 2,181 & 1,532 & 1,241 & 2,181 & \multicolumn{2}{|c|}{2,181} & \\
\hline Age 20-55 & $\begin{array}{c}-0.012 \\
(0.047)\end{array}$ & $\begin{array}{c}-0.022 \\
(0.050)\end{array}$ & $\begin{array}{c}0.022 \\
(0.057)\end{array}$ & $\begin{array}{l}-0.068 \\
(0.056)\end{array}$ & $\begin{array}{l}-0.079 \\
(0.063)\end{array}$ & $\begin{array}{l}-0.061 \\
(0.061)\end{array}$ & 0.60 \\
\hline $\mathrm{n}$ & 1,888 & 1,333 & 1,040 & 1,890 & \multicolumn{2}{|c|}{1,890} & \\
\hline Age $20-40$ & $\begin{array}{c}0.001 \\
(0.057)\end{array}$ & $\begin{array}{l}-0.010 \\
(0.061)\end{array}$ & $\begin{array}{c}0.075 \\
(0.071)\end{array}$ & - & \multirow[t]{2}{*}{ - } & \multirow[t]{2}{*}{ - } & \multirow[t]{2}{*}{0.65} \\
\hline $\mathrm{n}$ & 1,033 & 725 & 555 & & & & \\
\hline \multicolumn{8}{|c|}{$\begin{array}{l}\text { Note: }{ }^{*},{ }^{* *} \text { and }{ }^{* * *} \text { denote significance at the } 10 \%, 5 \% \text { and } 1 \% \text { level, respectively. Both indicators } \\
\text { range between } 0 \text { and } 1 \text { with } 1 \text { indicating very good health. Health at Present (next year) is coded in } 5 \text {, } \\
\text { Satisfaction with Health (next year) in } 11 \text { different values. The OLS results for the age group } 20-40 \\
\text { are only based on } 29 \text { persons who are in the treatment group in the treatment period. Hence, } \\
\text { statistical inference on these coefficients may be invalid. We do not report fixed-effects estimates for } \\
\text { this age group because we only have } 10 \text { persons with a within variation in the treatment indicator. For } \\
\text { the age groups } 20-64 \text { and } 20-55 \text { the number of persons with a within-variation in the treatment } \\
\text { indicator is } 26 \text { ( } 13 \text { switch on and } 17 \text { switch off) and } 21 \text { ( } 11 \text { switch on and } 13 \text { switch off), respectively. } \\
\text { Hence, these estimates have to be taken with a grain of salt. The fixed-effects switch-on and switch- } \\
\text { off estimates are obtained from a single fixed-effects regression equation. The "pre-reform mean" } \\
\text { refers to the treatment group in the pre-treatment period } 1994 \text { and } 1995 .\end{array}$} \\
\hline
\end{tabular}


Table 17

Effects on continuous sickness for at least 6 weeks

\begin{tabular}{|c|c|c|c|c|c|}
\hline OLS & $\begin{array}{c}\text { OLS - } \\
\text { switch on }\end{array}$ & $\begin{array}{l}\text { OLS - } \\
\text { switch off }\end{array}$ & FE & $\begin{array}{c}\text { FE - } \\
\text { switch on }\end{array}$ & $\begin{array}{c}\text { FE - } \\
\text { switch off }\end{array}$ \\
\hline
\end{tabular}

\section{6 continuous weeks ill}

\begin{tabular}{|c|c|c|c|c|c|c|c|}
\hline Age 20-64 & $\begin{array}{c}-0.024^{* *} \\
(0.012)\end{array}$ & $\begin{array}{l}-0.018 \\
(0.013)\end{array}$ & $\begin{array}{c}-0.027^{* *} \\
(0.013)\end{array}$ & $\begin{array}{l}-0.022^{*} \\
(0.011)\end{array}$ & $\begin{array}{c}-0.029 * * \\
(0.013)\end{array}$ & $\begin{array}{c}-0.014 \\
(0.013)\end{array}$ & 0.032 \\
\hline $\mathrm{n}$ & 23,702 & 13,451 & 16,351 & 23,702 & \multicolumn{2}{|c|}{23,702} & \\
\hline Age 20-55 & $\begin{array}{c}-0.032^{* * *} \\
(0.010)\end{array}$ & $\begin{array}{c}-0.035^{\star * *} \\
(0.012)\end{array}$ & $\begin{array}{c}-0.031^{* * *} \\
(0.011)\end{array}$ & $\begin{array}{c}-0.034^{* * *} \\
(0.011)\end{array}$ & $\begin{array}{c}-0.036^{* * *} \\
(0.013)\end{array}$ & $\begin{array}{c}-0.031^{* *} \\
(0.012)\end{array}$ & 0.028 \\
\hline $\mathrm{n}$ & 21,451 & 11,959 & 14,856 & 21,451 & \multicolumn{2}{|c|}{21,451} & \\
\hline Age $20-40$ & $\begin{array}{c}-0.021^{* *} \\
(0.010)\end{array}$ & $\begin{array}{l}-0.029^{*} \\
(0.015)\end{array}$ & $\begin{array}{l}-0.019^{*} \\
(0.010)\end{array}$ & $\begin{array}{l}-0.015 \\
(0.009)\end{array}$ & $\begin{array}{l}-0.012 \\
(0.012)\end{array}$ & $\begin{array}{l}-0.018 \\
(0.013)\end{array}$ & 0.020 \\
\hline ר & 12,097 & 6,338 & 8,552 & 12,097 & & & \\
\hline
\end{tabular}

6 continuous weeks ill (next year)

\begin{tabular}{|c|c|c|c|c|c|c|c|}
\hline Age 20-64 & $\begin{array}{c}-0.007 \\
(0.011)\end{array}$ & $\begin{array}{l}-0.009 \\
(0.015)\end{array}$ & $\begin{array}{l}-0.005 \\
(0.011)\end{array}$ & $\begin{array}{c}-0.002 \\
(0.010)\end{array}$ & $\begin{array}{c}-0.002 \\
(0.012)\end{array}$ & $\begin{array}{c}-0.002 \\
(0.013)\end{array}$ & 0.034 \\
\hline $\mathrm{n}$ & 23,702 & 13,451 & 16,351 & 23,702 & \multicolumn{2}{|c|}{23,702} & \\
\hline Age 20-55 & $\begin{array}{c}-0.012 \\
(0.011)\end{array}$ & $\begin{array}{c}-0.019 \\
(0.016)\end{array}$ & $\begin{array}{c}-0.008 \\
(0.011)\end{array}$ & $\begin{array}{c}-0.008 \\
(0.011)\end{array}$ & $\begin{array}{l}-0.006 \\
(0.012)\end{array}$ & $\begin{array}{l}-0.010 \\
(0.013)\end{array}$ & 0.031 \\
\hline $\mathrm{n}$ & 21,451 & 11,959 & 14,856 & 21,451 & \multicolumn{2}{|c|}{21,451} & \\
\hline Age $20-40$ & $\begin{array}{l}-0.016 \\
(0.010)\end{array}$ & $\begin{array}{l}-0.042^{*} \\
(0.023)\end{array}$ & $\begin{array}{l}-0.003 \\
(0.008)\end{array}$ & $\begin{array}{l}-0.002 \\
(0.009)\end{array}$ & $\begin{array}{c}0.013 \\
(0.012)\end{array}$ & $\begin{array}{c}-0.022 \\
(0.016)\end{array}$ & 0.016 \\
\hline $\mathrm{n}$ & 12,097 & 6,338 & 8,552 & 12,097 & & & \\
\hline
\end{tabular}

Note: ${ }^{*},{ }^{* *}$ and ${ }^{* * *}$ denote significance at the $10 \%, 5 \%$ and $1 \%$ level, respectively. The fixed-effects switch-on and switch-off estimates are obtained from a single fixed-effects regression equation. The "pre-reform mean" refers to the treatment group in the pre-treatment period 1994 and 1995.

Source: German Socio-Economic Panel (GSOEP), own calculations. 
Table 18

Effects on satisfaction with financial security in case of sickness

\begin{tabular}{|c|c|c|c|}
\hline All workers & OLS switch-off & FE switch-off & Pre-reform mean \\
\hline $\begin{array}{r}20-64 \\
n=5559\end{array}$ & $\begin{array}{c}0.014 \\
(0.020)\end{array}$ & $\begin{array}{l}-0.013 \\
(0.019)\end{array}$ & 0.66 \\
\hline $\begin{array}{r}20-55 \\
\mathrm{n}=4930\end{array}$ & $\begin{array}{c}0.027 \\
(0.020)\end{array}$ & $\begin{array}{c}-0.000 \\
(0.018)\end{array}$ & 0.65 \\
\hline $\begin{array}{r}20-40 \\
\mathrm{n}=2388\end{array}$ & $\begin{array}{c}0.007 \\
(0.031)\end{array}$ & $\begin{array}{c}0.000 \\
(0.030)\end{array}$ & 0.63 \\
\hline
\end{tabular}

Doctor visits $>0$

$\begin{array}{rccc}20-64 & 0.014 & -0.033 & 0.64 \\ \mathrm{n}=3,579 & (0.026) & (0.030) & \\ & & & \\ 20-55 & 0.032 & -0.010 & 0.64 \\ \mathrm{n}=3,103 & (0.027) & (0.030) & \\ & & & 0.62 \\ 20-40 & 0.001 & -0.000 & \\ \mathrm{n}=1,407 & (0.045) & (0.050) & \end{array}$

Days in hospital > 0

$\begin{array}{rccc}20-64 & 0.105^{* *} & - & 0.63 \\ \mathrm{n}=662 & (0.052) & & \\ & & - & 0.63 \\ 20-55 & 0.097^{*} & & \\ \mathrm{n}=560 & (0.055) & - & 0.64 \\ & & & \\ 20-40 & -0.150^{* *} & & \end{array}$

Note: ${ }^{*},{ }^{* *}$ and ${ }^{* * *}$ denote significance at the $10 \%, 5 \%$ and $1 \%$ level, respectively. The indicator ranges between 0 and 1 with 1 indicating a high satisfaction. The orgininal variable is coded in 11 different values. The OLS result for the age groups 20-64, 20.55 and 20-40 for those who have been in hospital is only based on 59,49 and 22 persons who are in the treatment group in the treatment period, respectively. Hence, statistical inference, especially on the negative point estimate for the age group 20-40 may be invalid, so that we do not take the statistical significance of this estimate seriously. We do not report fixed-effects estimates for the restriction on persons who were in hospital because we only have 3,3 , and 1 person with a within variation in the treatment indicator for the age groups 20-64, 20-55, and 20-40, respectively. The "pre-reform mean" refers to the treatment group in the pre-treatment period 1994 and 1995.

Source: German Socio-Economic Panel (GSOEP), own calculations. 


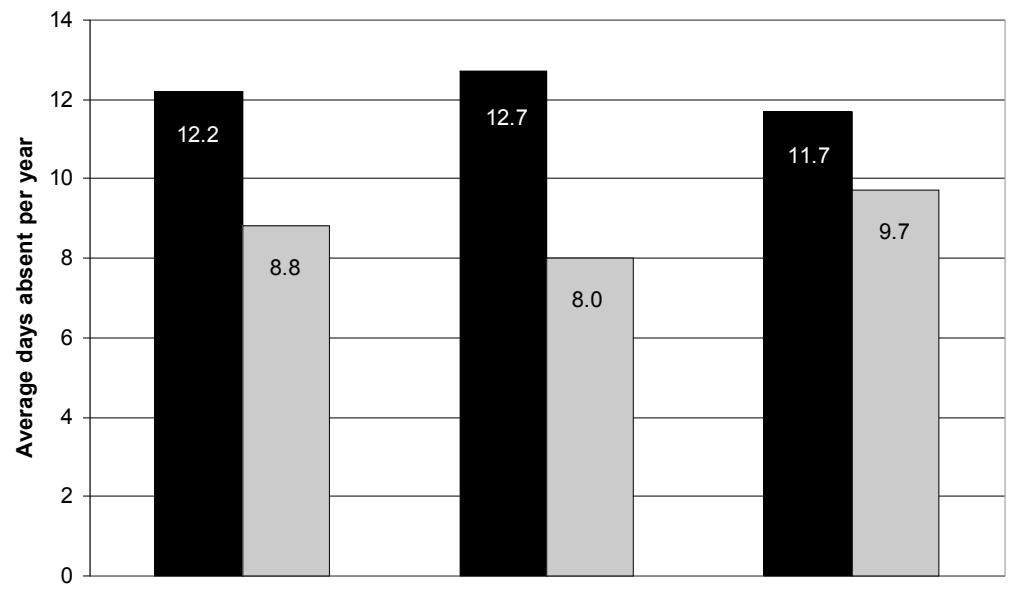

- Employee with collective agreement (control group)

$\square$ Employee without collective agreement (treatment group)

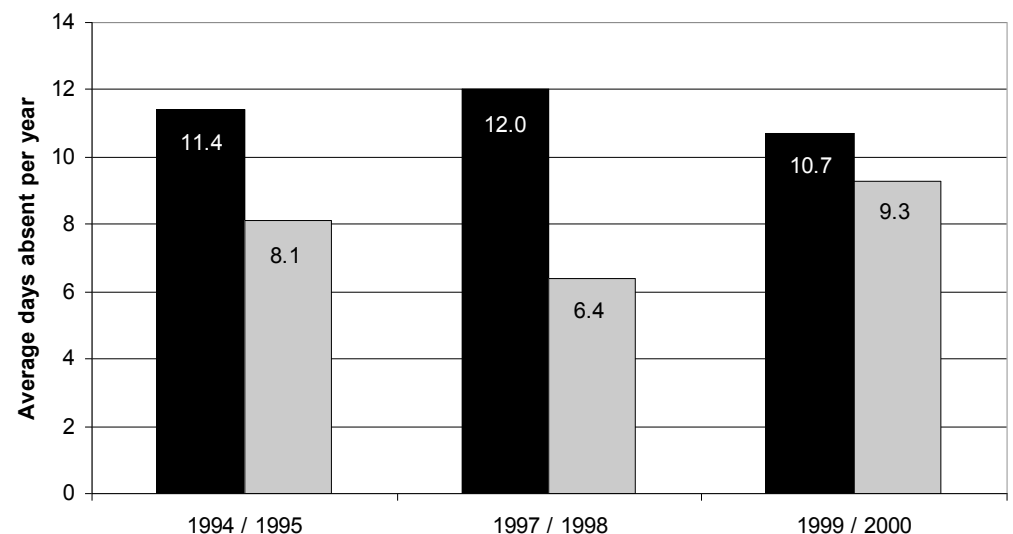

- Employee with collective agreement (control group) younger than 55

$\square$ Employee without collective agreement (treatment group) younger than 55

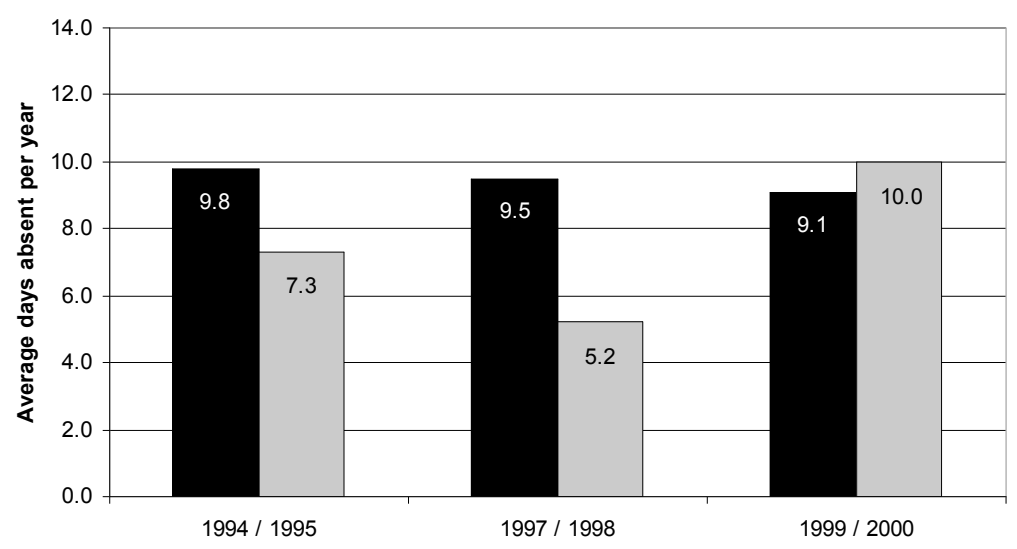

- Employee with collective agreement (control group) younger than 40

$\square$ Employee without collective agreement (treatment group) younger than 40

Fig. 1. Number of days absent over time by treatment status and age group

Note: We only observe the total number of days absent by calendar year, not the length of single spells of absence. The sample includes only firm stayers.

Source: German Socio-Economic Panel (GSOEP), own calculations. 


\section{Appendix}

Table A1

Sample selection

\begin{tabular}{ccccccc}
\hline Year & $\begin{array}{c}\text { Sample size } \\
\text { (including all } \\
\text { years) }\end{array}$ & $\begin{array}{c}\text { Individual is in } \\
\text { the sample this } \\
\text { year }\end{array}$ & $\begin{array}{c}\text { Individual is } \\
\text { also in the } \\
\text { sample the } \\
\text { following year }\end{array}$ & $\begin{array}{c}\text { Including only } \\
\text { employed } \\
\text { persons } \\
\text { between } 20 \\
\text { and 64 years } \\
\text { of age }\end{array}$ & $\begin{array}{c}\text { No missings } \\
\text { for questions } \\
\text { on absence }\end{array}$ & $\begin{array}{c}\text { Non insings } \\
\text { on questions } \\
\text { other } \\
\text { explanatory } \\
\text { variables }\end{array}$ \\
\hline 1994 & 56,150 & 13,417 & 12,520 & 6,288 & 6,040 & 5,134 \\
1995 & 56,150 & 13,768 & 12,851 & 6,526 & 6,278 & 5,576 \\
1997 & 56,150 & 13,283 & 12,180 & 5,931 & 5,658 & 4,964 \\
1998 & 56,150 & 14,670 & 13,373 & 6,394 & 6,160 & 5,428 \\
1999 & 56,150 & 14,085 & 13,035 & 6,443 & 6,196 & 5,263 \\
2000 & 56,150 & 24,586 & 21,233 & 10,083 & 9,690 & 8,527 \\
\hline$n$ & 336,900 & 93,809 & 85,192 & 41,665 & 40,022 & 34,892 \\
\hline
\end{tabular}

Source: German Socio-Economic Panel (GSOEP), own calculations.

Table A2

Selection of treatment and control groups

\begin{tabular}{cccccc}
\hline Year & Treated & Control & Movers & Rest & $n$ \\
\hline 1994 & 1,021 & 3,702 & 0 & 411 & 5,134 \\
1995 & 1,206 & 4,322 & 0 & 48 & 5,576 \\
1997 & 585 & 2,691 & 962 & 726 & 4,964 \\
1998 & 471 & 2,353 & 1,104 & 1,500 & 5,428 \\
1999 & 845 & 2,956 & 0 & 1,462 & 5,263 \\
2000 & 775 & 2,775 & 0 & 4,977 & 8,527 \\
\hline$n$ & 4,903 & 18,799 & 2,066 & 9,124 & 34,892
\end{tabular}

Note: To be part of either the treatment or control group in this study, an individual must have answered the question on collective bargaining in 1995. Hence, the number of observations is highest for both treated and control individuals in 1995. Panel attrition then works both backward and forward in time. So that observations can be classified into treatment and control, a worker must not have changed employer between 1996 and 1998 (i.e., until the end of the treatment period). Workers that have changed (termed "movers") are deleted from the sample. If, however, an individual answered the question on collective bargaining coverage in 1995 but changed employer before 1995 or in 1999/2000, we retain that employee in the sample. The last column, labeled "rest," includes workers who did not answer the question on collective bargaining in 1995, meaning that they cannot be classified as either treated or control and are therefore deleted from the sample. The allocation to the treatment or control group here is based on the 1995 information on collective bargaining coverage. It should also be noted that misclassification outside the treatment period is harmless because neither the treatment nor the control group was treated either before or after the repeal of the reform. Thus, keeping all persons who answered the 1995 question on collective bargaining coverage may improve precision in the repeated cross-section difference-in-differences estimates. In the fixed-effects estimates, the coefficient on treatment is driven only by observations present at least once in the treatment period and at least once in a non-treatment period. 
Table A3

Full estimation results

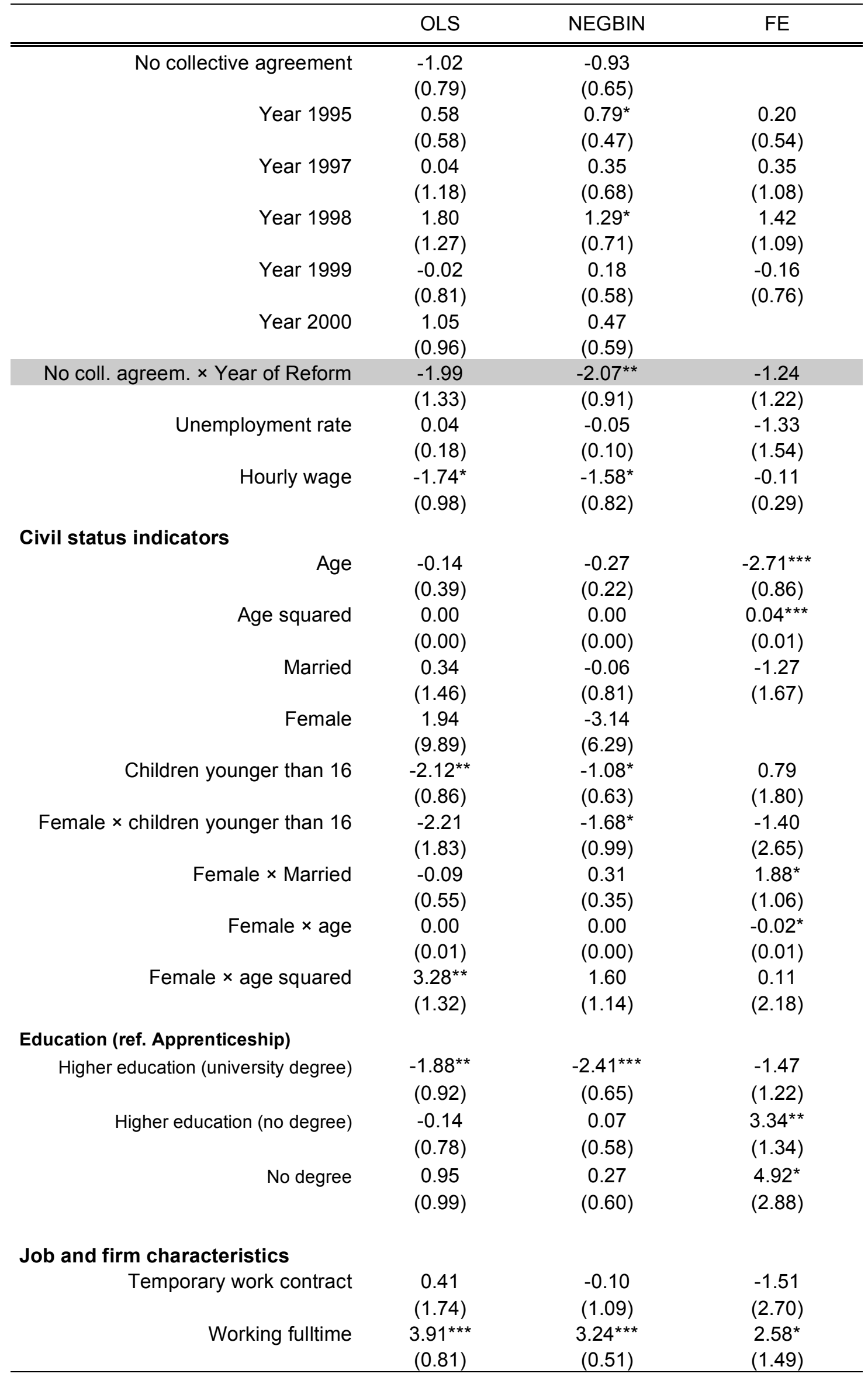


Table A3 (continued)

\begin{tabular}{|c|c|c|c|}
\hline & OLS & NEGBIN & FE \\
\hline \multicolumn{4}{|l|}{ Job and firm characteristics } \\
\hline \multirow[t]{2}{*}{ Blue-collar worker } & $4.18^{\star \star \star}$ & $4.57^{\star * \star}$ & $3.26^{* *}$ \\
\hline & $(0.78)$ & $(0.64)$ & $(1.58)$ \\
\hline \multirow[t]{2}{*}{ Civil servant } & 3.15 & $3.22^{* *}$ & -0.63 \\
\hline & $(2.10)$ & $(1.33)$ & $(2.88)$ \\
\hline \multicolumn{4}{|l|}{ Citizenship } \\
\hline \multirow[t]{2}{*}{ German } & -1.81 & -1.17 & 1.86 \\
\hline & $(1.12)$ & $(0.80)$ & (3.29) \\
\hline \multirow[t]{2}{*}{ West-Germany } & 0.94 & -0.20 & -3.06 \\
\hline & $(1.37)$ & $(0.87)$ & $(2.74)$ \\
\hline \multicolumn{4}{|l|}{ Firm size (ref. 1-19) } \\
\hline \multirow[t]{2}{*}{ Firm size (20-199) } & $2.42^{* \star *}$ & $2.04^{* * *}$ & -0.06 \\
\hline & $(0.77)$ & $(0.67)$ & $(1.37)$ \\
\hline \multirow[t]{2}{*}{ Firm size (200-1999) } & $2.17^{\star *}$ & $2.29^{* * *}$ & -1.63 \\
\hline & $(0.86)$ & $(0.73)$ & $(1.51)$ \\
\hline \multirow{2}{*}{ Firm size $(>2000)$} & $3.45^{\star * *}$ & $3.36^{\star * *}$ & -1.39 \\
\hline & $(0.88)$ & $(0.79)$ & $(1.72)$ \\
\hline \multicolumn{4}{|l|}{ Tenure (ref. $<1$ year) } \\
\hline \multirow[t]{2}{*}{ Tenure (1-3 years) } & -0.08 & -0.06 & $3.30^{*}$ \\
\hline & $(1.65)$ & $(1.45)$ & $(2.00)$ \\
\hline \multirow[t]{2}{*}{ Tenure (3-5 years) } & 1.21 & 1.13 & $4.66^{\star * *}$ \\
\hline & $(1.66)$ & $(1.60)$ & $(1.46)$ \\
\hline \multirow[t]{2}{*}{ Tenure (5-10 years) } & 0.03 & 0.60 & $4.22^{\star \star \star}$ \\
\hline & $(1.56)$ & $(1.54)$ & $(1.55)$ \\
\hline \multirow[t]{2}{*}{ Tenure ( $10-15$ years) } & 0.01 & -0.37 & $3.63^{* *}$ \\
\hline & $(1.65)$ & $(1.46)$ & $(1.65)$ \\
\hline \multirow[t]{2}{*}{ Tenure (15-20 years) } & -0.26 & 0.01 & $3.93^{* *}$ \\
\hline & $(1.68)$ & $(1.55)$ & $(1.80)$ \\
\hline \multirow[t]{2}{*}{ Tenure (>20 years) } & 0.46 & 0.03 & $5.91^{* * *}$ \\
\hline & $(1.72)$ & $(1.53)$ & $(2.23)$ \\
\hline \multicolumn{4}{|l|}{ Industry (ref. manufacturing) } \\
\hline \multirow[t]{2}{*}{ Agriculture, hunting and forestry } & $-2.81^{*}$ & -0.78 & -2.21 \\
\hline & $(1.47)$ & $(1.47)$ & $(2.10)$ \\
\hline \multirow[t]{2}{*}{ Mining and quarrying } & 5.64 & 7.80 & 17.82 \\
\hline & $(7.77)$ & $(8.80)$ & $(17.60)$ \\
\hline \multirow[t]{2}{*}{ Electricity, gas and water supply } & -1.66 & -0.46 & -1.64 \\
\hline & $(1.22)$ & $(1.12)$ & $(2.02)$ \\
\hline Construction & 1.07 & 1.22 & 1.78 \\
\hline & $(1.10)$ & $(0.84)$ & $(1.64)$ \\
\hline Wholesale \& retail trade & $0.33^{\prime}$ & 0.65 & 0.31 \\
\hline & $(0.88)$ & $(0.84)$ & $(1.96)$ \\
\hline Transport and communication & $4.81^{* *}$ & $3.56^{\star * *}$ & 1.46 \\
\hline & $(2.18)$ & $(1.34)$ & $(2.11)$ \\
\hline Financial intermediation & -0.36 & -0.60 & -1.67 \\
\hline & $(0.89)$ & $(0.81)$ & $(2.29)$ \\
\hline Real estate and business activities & 0.59 & 1.22 & 0.90 \\
\hline & $(1.04)$ & $(0.95)$ & $(1.64)$ \\
\hline Public administration and defence & 0.59 & 1.29 & -0.67 \\
\hline & $(1.43)$ & $(0.87)$ & $(1.93)$ \\
\hline Education & -0.26 & 0.59 & 1.24 \\
\hline & $(1.49)$ & $(1.07)$ & (2.88) \\
\hline
\end{tabular}


Table A3 (continued)

\begin{tabular}{|c|c|c|c|}
\hline & OLS & NEGBIN & FE \\
\hline \multicolumn{4}{|l|}{ Industry (ref. manufacturing) } \\
\hline \multirow[t]{2}{*}{ Health and social work } & $2.84^{* *}$ & $2.50^{* \star *}$ & 0.04 \\
\hline & $(1.23)$ & $(0.95)$ & $(1.79)$ \\
\hline \multirow[t]{2}{*}{ Other social \& personal service } & $2.28^{*}$ & $2.74^{*}$ & 1.96 \\
\hline & $(1.28)$ & $(1.56)$ & $(1.77)$ \\
\hline \multicolumn{4}{|l|}{$\begin{array}{l}\text { Health at present } \\
\text { (ref. satisfactory) }\end{array}$} \\
\hline Very poor & $\begin{array}{c}38.52^{* * *} \\
(6.40)\end{array}$ & $\begin{array}{c}21.65^{* * *} \\
(4.06)\end{array}$ & $\begin{array}{c}30.70^{* * *} \\
(6.07)\end{array}$ \\
\hline Poor & $\begin{array}{c}11.54^{* * *} \\
(1.52)\end{array}$ & $\begin{array}{c}6.69^{* * *} \\
(1.02)\end{array}$ & $\begin{array}{l}8.16^{* * *} \\
(2.16)\end{array}$ \\
\hline Good & $-2.47^{* * *}$ & $-2.66^{* * *}$ & -1.06 \\
\hline & $(0.58)$ & $(0.43)$ & $(0.75)$ \\
\hline Very good & $-5.02^{* \star *}$ & $-4.66^{\star \star *}$ & $-1.73^{*}$ \\
\hline & $(0.86)$ & $(0.56)$ & $(0.96)$ \\
\hline \multicolumn{4}{|l|}{$\begin{array}{l}\text { Satisfaction with health } \\
\text { (ref. satisfactory) }\end{array}$} \\
\hline Very poor & 7.59 & $4.84^{* *}$ & 1.76 \\
\hline & $(6.44)$ & $(2.35)$ & $(6.75)$ \\
\hline \multirow[t]{2}{*}{ Poor } & $4.32^{* *}$ & $2.24^{\star \star \star}$ & $3.50^{*}$ \\
\hline & $(1.79)$ & $(0.85)$ & $(2.10)$ \\
\hline \multirow{2}{*}{ Good } & $-1.96^{* * *}$ & $-2.14^{* * *}$ & $-1.94^{* * *}$ \\
\hline & $(0.56)$ & $(0.41)$ & $(0.72)$ \\
\hline \multirow{2}{*}{ Very good } & -1.22 & $-1.60^{* * *}$ & -1.15 \\
\hline & $(0.84)$ & $(0.60)$ & $(0.88)$ \\
\hline $\mathrm{n}$ & 23,702 & 23,702 & 23,702 \\
\hline $\mathrm{R}^{2}$ & 0.11 & & 0.04 \\
\hline
\end{tabular}

Note: ${ }^{*},{ }^{* *}$ and ${ }^{* * *}$ denote significance at the $10 \%, 5 \%$ and $1 \%$ level, respectively.

Source: German Socio-Economic Panel (GSOEP), own calculations. 